\title{
Evolution of the Early Permian volcanic-plutonic complex in the western part of the Permian Gobi-Altay Rift (Khar Argalant Mts., SW Mongolia)
}

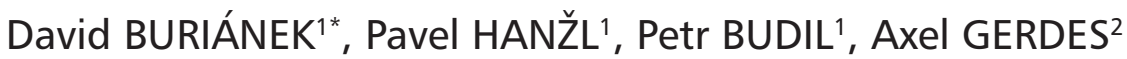 \\ ${ }^{1}$ Czech Geological Survey, Klárov 3, 11821 Prague 1, Czech Republic; david.burianek@geology.cz \\ ${ }^{2}$ Institut für Geowissenschaften, J. W. Goethe Universität, Altenhöferallee 1, 60438 Frankfurt am Main, Germany \\ ${ }^{*}$ Corresponding author
}

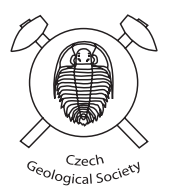

\begin{abstract}
The Lower Permian volcano-sedimentary complexes of the Khar Argalant and Delger Khangay formations in the Khar Argalant Mts. in south-western Mongolia are products of postorogenic within-plate magmatic activity. They consist of terrestrial lavas and pyroclastic flows with local intercalations of clastic sedimentary rocks. Vascular plants in volcanoclastic layers correspond to typical Lower to Middle Permian terrestrial associations formed under dry to intermediate conditions of temperate to colder climatic zones. The plant communities of all three formations show affinities to the Siberia (Angara) - "Cordaitean taiga".

Relationships of volcanic rocks suggest simultaneous eruptions of mafic (basalt to trachyandesite) and felsic (trachyte to rhyolite) lavas. The rocks of both formations have similar major- and trace-element contents as well as volcanological character. The granite of the Shar Oroy Massif, with zircon concordia age of $285 \pm 1$ Ma, was roughly contemporaneous with the volcanic rocks of the Delger Khangay Fm. The Early/Late Permian clastic sedimentary rocks of the Butnaa Khudag Fm. in the hanging wall of the Delger Khangay Fm. postdated the terrestrial volcanic events. Geochemical and structural characteristics suggest that the Shar Oroy Massif and the surrounding Permian volcanic suite represent an eroded, shallow-level plutonic centre and its eruptive cover, which evolved during a crustal extension.
\end{abstract}

Keywords: Mongolia, Permian Gobi-Altay Rift, volcanic-plutonic complexes, geochemistry, zircon dating, fossil flora

Received: 16 January 2012; accepted: 12 June 2012; handling editor: M. Štemprok

The online version of this article (doi: 10.3190/jgeosci.116) contains supplementary electronic material.

\section{Introduction}

The Permian-Triassic magmatic activity in Mongolia was contemporaneous with the final stages of consolidation of the Central Asian Orogenic Belt (CAOB) (Xiao et al. 2003). The CAOB is a large mosaic of various geological terranes amalgamated between the Siberian Block in the north, the Tarim Block in the southwest and the Sino-Korean Block in the south (Hendrix et al. 1992; Sengör et al. 1993; Jahn et al. 2000; Dergunov 2001). Suturing in the southern part of the CAOB proceeded eastwards from the latest Palaeozoic in the Tien Shan to the Triassic in Inner Mongolia (Xixi et al. 1990; Xiao et al. 2004, 2008) and was accompanied by intracontinental magmatic activity in the terranes accreted to the southern margin of the Siberia craton (Zhu et al. 2001; Zhang et al. 2008; Jahn et al. 2009).

Yarmolyuk and Kovalenko $(1991,2001)$ assumed the existence of five linear systems controlled by large E-W oriented faults and related to Upper Palaeozoic igneous bimodal associations. These zones are (from south to north): Gobi-Tien Shan, Main Mongolian Lineament, Gobi-Altay, North Gobi and North Mon-
golian-Transbaikalian (Fig. 1 inset). These structures represent the parts of the Asian rift system (Kovalenko and Chernov 2008).

Lower Permian volcanic and volcano-sedimentary rocks and associated granitoids of the Shar Oroy Massif crop out in the Khar Argalant mountain range (Fig. 1a) at the northern rim of the Gobi Altay. The area is in the southwestern part of the $\mathrm{CAOB}$ and to the north of the Main Mongolian Lineament (Tomurtogoo 1997) which separated tectonostratigraphic zones formed during the Variscan orogeny in the south from Cadomian/ Caledonian blocks in the north (Zaitsev et al. 1970; Zonenshain 1973; Markova 1975; Ruzhentsev 2001; Badarch et al. 2002).

This paper presents new geochronological and geochemical data from the Permian bimodal volcanoplutonic association in the western Gobi-Altay rift zone (Fig. 1a). We also discuss inconsistencies in the lithological subdivision of the Permian volcanic and volcano-sedimentary formations in the Khar Argalant mountain range. Study area is located in southwestern Mongolia, about $670 \mathrm{~km}$ southwest of the capital Ulaanbaatar. 

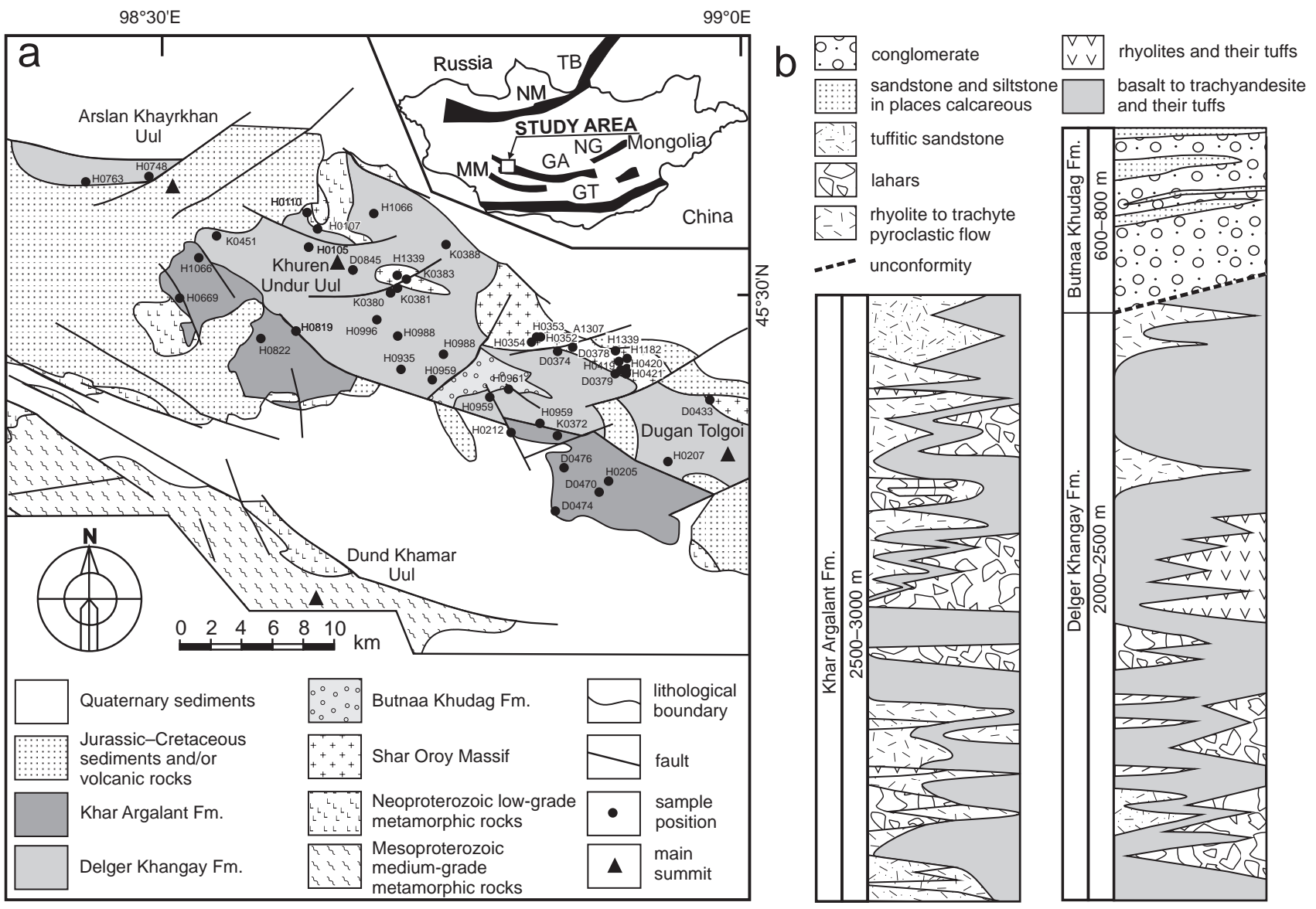

Fig. 1 Inset: Late Palaeozoic and Early Cretaceous rift zones and continental-margin belts in Mongolia (insert; GT - Gobi-Tien Shan, MM - Main Mongolian Lineament, GA - Gobi-Altay, NG - North Gobi, NM and TB - North Mongolian-Transbaikal rifts) modified from Chernov and Kovalenko (2008). a - Simplified geological map of the Khar Argalant mountain range based on mapping by Hanžl and Aichler eds. (2007). The locations of the geochemical samples (Tab. 1) are also shown. b - Generalized lithological stratigraphic columns of the Khar Argalant, Delger Khangay and Butnaa Khudag fms.

\section{Geological setting}

The Permian rift-related volcanic rocks in western GobiAltay range were firstly described by Yarmolyuk (1983). The Delger Khangay, Khar Argalant and Butnaa Khudag formations were distinguished in the geological maps by Rauzer et al. (1987) and Hanžl and Aichler eds. (2007). These volcano-sedimentary and sedimentary formations cover the Neoproterozoic to Early Palaeozoic rocks of the Lake Zone in its easternmost exposures. The Lake Zone consists of the Proterozoic to Palaeozoic, slightly metamorphosed volcano-sedimentary sequences, which alternate in a tectonic mosaic with highly metamorphosed rocks as well as the oceanic crust relics. The evolution of the Lake Zone culminated in the formation of the lower Palaeozoic island arc (Lamb and Badarch 2001; Badarch et al. 2002).

The Lake Zone in the area of interest is built by the Cambrian limestones, Neoproterozoic medium-grade metamorphic rocks of the Zamtyn Nuuru Crystalline Complex, Neoproterozoic ophiolite (Khan Taishir Fm.) and high-grade metamorphic rocks of the Tsakhir Uul Crystalline Complex (Hanžl and Aichler eds. 2007; Hrdličková et al. 2008; Kröner et al. 2010; Lehmann et al. 2010; Štípská et al. 2010). The volcanic and sedimentary rocks in the Khar Argalant Mts. were intruded by the Shar Oroy granitoid Massif coeval with the Permian volcanic rocks (Borzakovskii et al. 1985). While the Delger Khangay and Khar Argalant formations are volcanic complexes with subordinate sedimentary layers, the Butnaa Khudag Fm. has a molasse character and discordantly covers the volcanic rocks (Fig. 1b). Permian sequences in the Khar Argalant Mts. are overlain by Mesozoic sediments with sheets of basaltic lavas and rhyolitic agglomerates (Buriánek et al. 2008) in the $\mathrm{E}$ and $\mathrm{W}$ and are restricted by Cenozoic faults in the $\mathrm{N}$ and $\mathrm{S}$.

\section{Analytical techniques}

We took 48 samples (Tab. 1), which show variations in the chemical composition as well as mineralogical and 
Tab. 1 Localization of the studied samples

\begin{tabular}{|c|c|c|c|c|c|}
\hline Sample & Rock & Type of occurrence & Formation & Longitude $\left({ }^{\circ} \mathrm{E}\right)$ & Latitude $\left({ }^{\circ} \mathrm{N}\right)$ \\
\hline H1244 & rhyolite & dome & Khar Argalant Fm. & 98.30708 & 45.57911 \\
\hline H0748 & rhyolite & dome & Khar Argalant Fm. & 98.47342 & 45.56739 \\
\hline K0372 & rhyolite & dome & Khar Argalant Fm. & 98.84050 & 45.41290 \\
\hline D0474 & rhyolite & dome & Khar Argalant Fm. & 98.83610 & 45.36945 \\
\hline D0476 & rhyolite & lava flow & Khar Argalant Fm. & 98.84589 & 45.39281 \\
\hline H0205 & rhyolite & lava flow & Khar Argalant Fm. & 98.90534 & 45.37591 \\
\hline D0470 & trachyte & lava flow & Khar Argalant Fm. & 98.89590 & 45.36983 \\
\hline H0763 & trachyte & lava flow & Khar Argalant Fm. & 98.42446 & 45.56677 \\
\hline H0822 & trachyte & lava flow & Khar Argalant Fm. & 98.58391 & 45.47667 \\
\hline H0669 & basalt & lava flow & Khar Argalant Fm. & 98.52326 & 45.49158 \\
\hline H0819 & basalt & lava flow & Khar Argalant Fm. & 98.61050 & 45.48058 \\
\hline $\mathrm{H} 1052$ & basalt & lava flow & Khar Argalant Fm. & 98.51738 & 45.51214 \\
\hline K0451 & rhyolite & dome & Delger Khangay Fm. & 98.55178 & 45.52195 \\
\hline H0105 & rhyolite & lava flow & Delger Khangay Fm. & 98.63196 & 45.51347 \\
\hline K0388 & trachyte & dike & Delger Khangay Fm. & 98.73804 & 45.52474 \\
\hline H0935 & trachyte & lava flow & Delger Khangay Fm. & 98.73125 & 45.44652 \\
\hline H0996 & trachyte & lava flow & Delger Khangay Fm. & 98.67708 & 45.47798 \\
\hline D0845 & tuff & layer & Delger Khangay Fm. & 98.65227 & 45.51035 \\
\hline H0988 & trachyandesite & lava flow & Delger Khangay Fm. & 98.73165 & 45.46542 \\
\hline H0107 & trachyandesite & lava flow & Delger Khangay Fm. & 98.63577 & 45.53114 \\
\hline H1339 & trachyandesite & lava flow & Delger Khangay Fm. & 98.70977 & 45.51484 \\
\hline K0381 & trachyandesite & lava flow & Delger Khangay Fm. & 98.71828 & 45.51130 \\
\hline H0110 & trachyandesite & lava flow & Delger Khangay Fm. & 98.62462 & 45.54292 \\
\hline H0207 & basalt & lava flow & Delger Khangay Fm. & 98.93324 & 45.39780 \\
\hline H0207 & basalt & dike & Delger Khangay Fm. & 98.93324 & 45.39780 \\
\hline H0959 & basalt & lava flow & Delger Khangay Fm. & 98.78217 & 45.43669 \\
\hline H0961 & basalt & lava flow & Delger Khangay Fm. & 98.79592 & 45.44091 \\
\hline H1066 & basalt & lava flow & Delger Khangay Fm. & 98.67297 & 45.54875 \\
\hline K0383 & basalt & lava flow & Delger Khangay Fm. & 98.72213 & 45.51563 \\
\hline D0374 & rhyolite & dike & Shar Oroy Massif & 98.84875 & 45.47068 \\
\hline A1307 & trachyte & dike & Shar Oroy Massif & 98.82352 & 45.48561 \\
\hline A 2104 & basalt & dike & Shar Oroy Massif & 98.78732 & 45.51463 \\
\hline H0422 & basalt & dike & Shar Oroy Massif & 98.86991 & 45.46865 \\
\hline D0354 & syenite & body & Shar Oroy Massif & 98.81922 & 45.47491 \\
\hline D0372 & syenite & body & Shar Oroy Massif & 98.84706 & 45.46901 \\
\hline D0378 & granite & dike & Shar Oroy Massif & 98.86537 & 45.46026 \\
\hline K0380 & granite & body & Shar Oroy Massif & 98.71625 & 45.50970 \\
\hline D0433 & granite & body & Shar Oroy Massif & 98.96814 & 45.43414 \\
\hline H0419 & granite & body & Shar Oroy Massif & 98.87661 & 45.45746 \\
\hline H0420 & granite & body & Shar Oroy Massif & 98.87746 & 45.45811 \\
\hline H1182 & granite & body & Shar Oroy Massif & 98.63170 & 45.54730 \\
\hline H0421 & monzonite & body & Shar Oroy Massif & 98.87931 & 45.45983 \\
\hline H1182 & gabbro & body & Shar Oroy Massif & 98.63170 & 45.54730 \\
\hline H0420B & gabbro & enclave & Shar Oroy Massif & 98.87746 & 45.45811 \\
\hline D0353 & gabbro & body & Shar Oroy Massif & 98.82193 & 45.47580 \\
\hline D0352 & monzogabbro & enclave & Shar Oroy Massif & 98.82467 & 45.47442 \\
\hline H1339 & monzogabbro & body & Shar Oroy Massif & 98.70977 & 45.51484 \\
\hline D0378 & monzogabbro & enclave & Shar Oroy Massif & 98.86537 & 45.46026 \\
\hline H0212 & monzogabbro & body & Shar Oroy Massif & 98.79202 & 45.41534 \\
\hline
\end{tabular}


textural characteristics. Whole-rock major- and traceelement analyses were carried out at Acme Analytical Laboratories, Ltd., Vancouver, Canada. Major oxides were analysed by the Inductively Coupled Plasma Mass Spectrometry (ICP-MS) method. Loss on ignition (LOI) was calculated from the weight difference after ignition at $1000{ }^{\circ} \mathrm{C}$. The trace elements were analysed by Instrumental Neutron Activation Analysis (INAA) and ICP-MS following $\mathrm{LiBO}_{2}$ fusion. The detection limits for analyses were between 0.01 and 0.1 wt. $\%$ for the major elements, and between 0.1 and $8 \mathrm{ppm}$ for the trace elements. The geochemical data were plotted and recalculated using the GCDkit software package (Janoušek et al. 2006).

The fractional crystallization and magma mixing in rocks of Shar Oroy Massif were interpreted in MS Excel spreadsheet using a FC-AFC-FCA and mixing modeller (Ersoy and Helvac1 2010).

Zircons from granite sample H0420 were analysed for $\mathrm{U}, \mathrm{Th}$ and $\mathrm{Pb}$ isotopes by laser-ablation ICP-MS at Goethe-University Frankfurt, using a Thermo-Finnigan Element II sector field ICP-MS coupled to a New Wave UP213 ultraviolet laser system (Gerdes and Zeh 2006, 2009). Laser spot sizes varied from 20 to $40 \mu \mathrm{m}$ and were placed based on the SEM and CL images of the individual grains. The ablation crater has a typical depth of $\sim 20$ $\mu \mathrm{m}$. Twenty-five analyses were carried out on 25 grains including all the different types of oscillatory zoning.

The selected samples were analysed for the $\mathrm{Sr}$ and $\mathrm{Nd}$ isotopic compositions in the laboratories of the Czech Geological Survey. Samples were dissolved using combined $\mathrm{HF}-\mathrm{HCl}-\mathrm{HNO}_{3}$ decomposition. Strontium and bulk REE were separated by cation-exchange chromatography using BioRad AG-W X8 resin loaded into quartz columns. Neodymium was further separated on quartz columns with S-X8 Biobeads coated with HDEHP (Richard et al. 1976). The isotopic composition was analysed on a Finnigan MAT 262 thermal ionization mass spectrometer in the dynamic mode using a double Re filament assembly for both $\mathrm{Sr}$ and Nd. The NBS 987 reference material yielded a long-time ${ }^{87} \mathrm{Sr} /{ }^{86} \mathrm{Sr}$ average of $0.710244(1 \sigma=0.000013,27$ values $)$, while the $\mathrm{Nd} \mathrm{La}$ Jolla average ${ }^{143} \mathrm{Nd} /{ }^{144} \mathrm{Nd}$ was $0.511852(1 \sigma=0.000007$, 25 values). The decay constants employed to age-correct the isotopic ratios were taken from Steiger and Jäger (1977) (Sr) and Lugmair and Marti (1978) (Nd). The $\varepsilon_{285}^{\mathrm{Nd}}$ values were obtained using the Bulk Earth parameters of Jacobsen and Wasserburg (1980).

Electron microprobe analyses (EMPA) were performed on the Cameca SX-50 instrument in the Joint Laboratory of Electron Microscopy and Microanalysis of Masaryk University and the Czech Geological Survey (Brno, Czech Republic), by R. Čopjaková. A wavelength-dispersion mode with a beam diameter of 4-5 $\mu \mathrm{m}$, accelerating potential of $15 \mathrm{kV}$ and sample current of $20 \mathrm{nA}$ were used for $\mathrm{Si}, \mathrm{Al}, \mathrm{Ti}, \mathrm{Fe}, \mathrm{Mn}, \mathrm{Mg}, \mathrm{Ca}, \mathrm{Na}$ and $\mathrm{K}$. A higher current of $40 \mathrm{nA}$ was employed for $\mathrm{Zn}, \mathrm{F}$ and $\mathrm{P}$; the counting time was $20 \mathrm{~s}$ for all the elements. The following standards were used $\left(\mathrm{K}_{\alpha} \mathrm{X}\right.$-ray lines): diopside ( $\mathrm{Si}$, $\mathrm{Ca})$, kyanite $(\mathrm{Al})$, fayalite $(\mathrm{Fe})$, rutile $(\mathrm{Ti})$, pyrope $(\mathrm{Mg})$, spessartine $(\mathrm{Mn})$, albite $(\mathrm{Na})$, orthoclase $(\mathrm{K})$, fluorapatite $(\mathrm{P}, \mathrm{F})$ and gahnite $(\mathrm{Zn})$.

The paleontological data are based on findings collected during the fieldwork of the Czech Geological Survey expedition (Hanžl and Aichler eds. 2007).

\section{Geology}

\subsection{Delger Khangay Formation}

The Delger Khangay Fm. was described by Mosiondze (in Zabotkin ed. 1983) as an Upper Permian complex in the NW-SE belt exposed between the Arslan Khayrkhan Mt. and Dugan Tolgoi Mt. The unit is separated in the SW from the Khar Argalant Fm. by a fault. The footwall of volcanic rocks is formed by the rocks of the Neoproterozoic Khan Taishir Fm. Conglomerates of the Butnaa Khudag Fm. occur in the hanging wall (Fig. 1b). A granite apophysis of the Shar Oroy Massif intruded the Permian volcanic rocks (Fig. 2a) in the northern and eastern parts of the Khar Argalant mountain range. The volcanic complex as well as the Shar Oroy Massif was intruded by a number of basaltic to rhyolitic dikes.

According to Rauzer et al. (1987), the Delger Khangay Fm. is of Lower Permian age. Bedding planes in tuffaceous parts of the formation exhibit a very variable orientation. They are flat to moderately inclined without a preferred orientation. Lithologies are exposed in irregular NE-SW to E-W trending belts. The boundaries between different types of volcanic rocks are usually gradual.

\subsubsection{Sedimentary and epiclastic volcanic rocks}

Sandstones and conglomerates are exposed only in the northern part of the Khar Argalant mountain range and probably represent the upper part of a volcanic sequence c. 150-200 m thick (Fig. 1b). The sandstones are grainsupported, often with clay or calcite porous cement. Most quartz and plagioclase detrital grains are angular; subrounded to rounded quartz grains were also found. In some places, the sandstones alternate with rhyolitic tuffs. Conglomerates with subangular to rounded clasts of acid volcanic rocks are present in the lower part of the sequence. The beds of red sandstones passing gradually into red marlstones and nodular limestones are exposed 

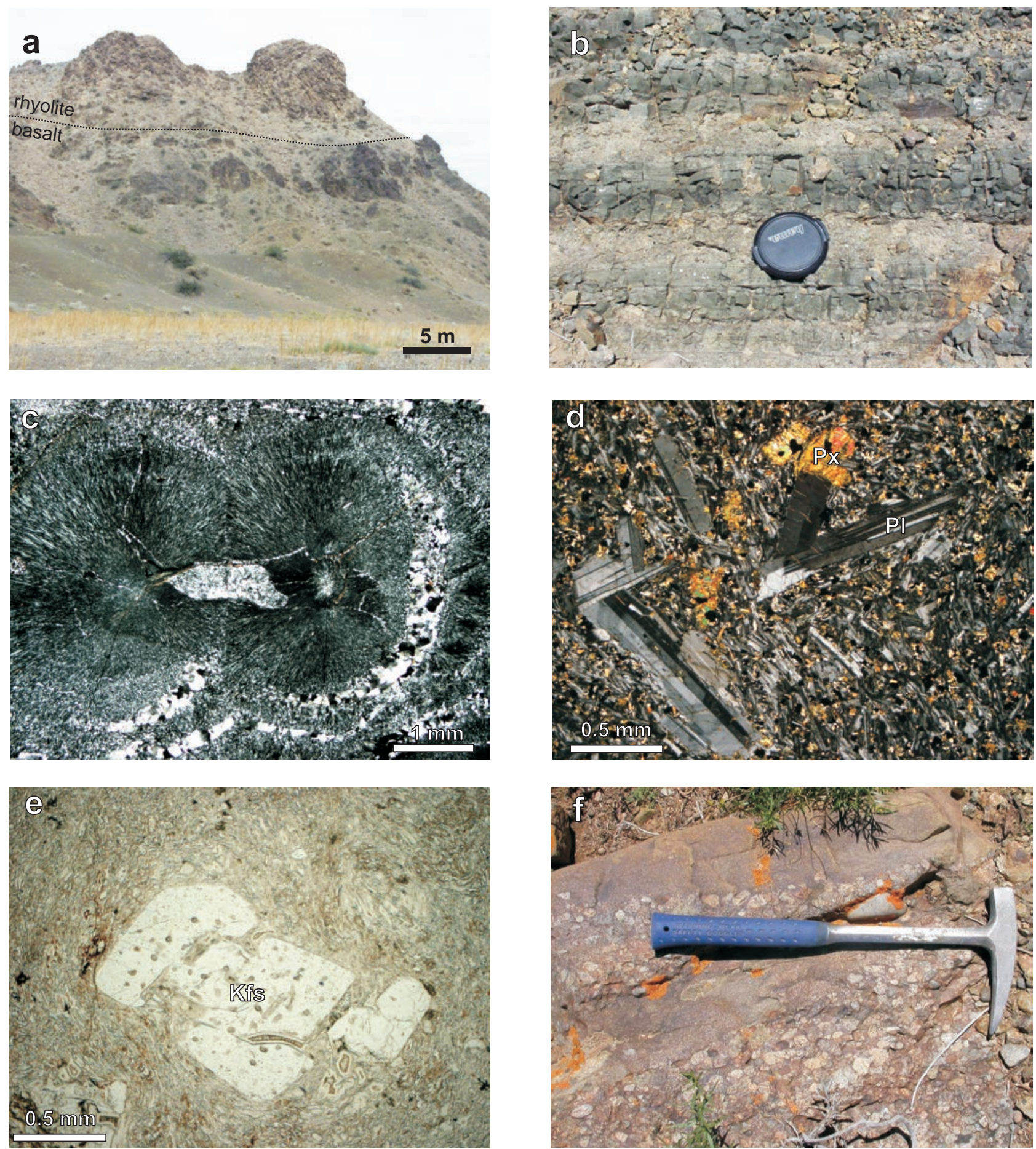

Fig. 2 Field photographs and photomicrographs documenting observations from the Delger Khangay, Khar Argalant and Butnaa Khudag formations: $\mathbf{a}$ - rhyolite lava dome in the hanging wall of the basalt lava flows, SE part of the Delger Khangay Fm.; $\mathbf{b}$ - volcano-sedimentary rocks (interbedded reworked tuffs and siltstones), Delger Khangay Fm.; c - spherulitic rhyolite from the Delger Khangay Fm., crossed nicols; d - porphyritic basalt from the Delger Khangay Fm., crossed nicols; e - welded ignimbrite with K-feldspar phenocryst from the Khar Argalant Fm., plane polarized light; $\mathbf{f}$ - interbedded sandstones and conglomerates of the Butnaa Khudag Fm.

in the hanging wall. Fine-grained muddy limestones are poorly bedded with characteristic nodules up to $20 \mathrm{~cm}$ in size.
Epiclastic volcanic rocks consist of medium- to finegrained matrix-supported tuffaceous sandstones, often with layers of laminated siltstones (Fig. 2b), conglomer- 
ates and reworked tuffs. Tuffaceous sandstones also occur as lenses among amygdaloidal basalts. Epiclastic volcanic rocks are poorly sorted and contain common angular to subangular clasts of trachybasalts and rhyolites and also quartz and/or feldspar grains. The tuffaceous matrix is very fine-grained and volcanic ash locally predominates. Volcanic glass in the matrix is almost completely replaced by clay minerals, limonite, and chalcedony.

\subsubsection{Volcanic rocks}

Acid to intermediate igneous rocks are mainly exposed in a NW-SE, up to $800 \mathrm{~m}$ thick belt in the central part of the Khar Argalant mountain range. Rhyolites form lava flows and domes from a few metres up to a few tens of metres thick (Fig. 2a). They are spatially related to a belt of amygdaloidal basalts along the boundary with the Khar Argalant Fm. Rhyolites are grey, white or reddish, locally finely laminated, porphyritic rocks. Alkali feldspars and/or quartz phenocrysts are euhedral to subhedral. The very fine-grained felsitic groundmass consists of feldspars, quartz and clay minerals. Granophyric textures (intergrowths of quartz and potassium feldspar) or spherulites (Fig. 2c) are locally present. Porphyric trachyte lava flows are often present and alternate with layers of ignimbrites.

Ignimbrite typically contains a moderate to low content of plagioclase (10-25 vol. \%) and/or euhedral quartz crystals (5-30 vol. \%), with common angular to subrounded lithic clasts. The vitreous matrix usually displays welding or flow fabric, with local several $\mathrm{cm}$ thick unwelded layers on the top of the ignimbrite flows.

Trachyandesites to basaltic lavas predominate in the Delger Khangay Fm. Trachyandesites are composed of plagioclase phenocrysts set in a fine-grained groundmass of microcrystalline plagioclase and chlorite and/or glass. Plagioclase phenocrysts are maximally a few $\mathrm{cm}$ in size, locally oscillatory zoned and partially altered. Amygdales up to $3 \mathrm{~cm}$ in diameter are filled with quartz, carbonate, chalcedony, clay and chlorites. Basalts are fine-grained and commonly showing porphyritic or ophitic textures (Fig. 2d). Olivine is often present as phenocrysts (partially resorbed and replaced by the minerals of the serpentine group). Lath-shaped plagioclase crystals are enclosed in pyroxene or amphibole. Plagioclase is occasionally altered and saussuritized. Pyroxene is partially chloritized. Volcanic glass is often replaced by secondary minerals.

Basaltic tuffs form up to $2 \mathrm{~m}$ thick layers in the basalt to trachyandesite lavas, mainly along the contact with the Khar Argalant Fm. Basaltic tuffs are very fine-grained with pyroxene, biotite or plagioclase phenocrysts or medium-grained showing pyroclastic textures (lapilli, volcanic ash and lithic fragments). Pyroxene is partly replaced by amphibole.

\subsection{Khar Argalant Formation}

The rocks of the Khar Argalant Fm. form the SW slopes of the Khar Argalant mountain range. They discordantly cover the Neoproterozoic to Cambrian rocks of the Lake Zone. The NW-SE trending fault zone overprints the contact with the Delger Khangay Fm. Rauzer et al. (1987) described a stratigraphical contact of formations, whereby the Delger Khangay Fm. rests upon the Khar Argalant Fm. concordantly but with washouts. The thickness of the formation is estimated to be up to two kilometres.

Early/Middle Permian age was determined in layers of tuffaceous siltstones in the NW part of the formation by the flora remains (Rufloria? sp., seeds of Cardiocarpus sp. - probably belong to the foils of Rufloria, remains of horsetails Annularia cf. undulata, Annularia sp., Calamites sp. etc., see Fig. 3a-d).

Bedding planes are predominantly NW-SE oriented, with medium to steep dips to the NE and SW. These orientations suggest folding of the rocks into large open folds. Cleavage is WNW-ESE striking and subvertical. Fold axes gently plunge to the WNW.

\subsubsection{Sedimentary and epiclastic volcanic rocks}

Sedimentary and epiclastic volcanic rocks are exposed in the Khar Argalant Fm. as intercalations, several meters thick, between lava flows. They occur most commonly in the NW part of the unit.

Epiclastic volcanic rocks of variable colours are represented by tuffaceous sandstones ranging to finely laminated tuffaceous siltstones with layers of arkose sandstone to siltstone. The contacts between the different types of volcano-sedimentary rocks are gradual. The fine-grained tuffaceous sandstones contain lenses and thin (a few $\mathrm{cm}$ thick) beds of coal and coal-bearing siltstones with common flora relics. Tuffaceous siltstones contain small fragments of altered volcanic glass and subangular quartz or quartz-feldspar aggregates. Poorly sorted arkoses contain mainly plagioclase grains. Felsic rock fragments and quartz are much less abundant. Conglomerates are clast- as well as matrix-supported, forming layers up to several metres thick. Prevailing clasts of acid lavas and ignimbrites (25-40 vol. \%) and quartz (30-35 vol. \%) are subangular to rounded shape. Rounded limestone (0-25 vol. \%), basic volcanic rocks $(0-18$ vol. \%) and sandstone $(0-5$ vol. \%) pebbles are locally present.

Lahars are common in the NW part of the unit. They are thickly bedded and clast-supported. Angular fragments consist of andesitic basalts, rhyolites, dacites and fine-grained granophyric to porphyritic subvolcanic gran- 

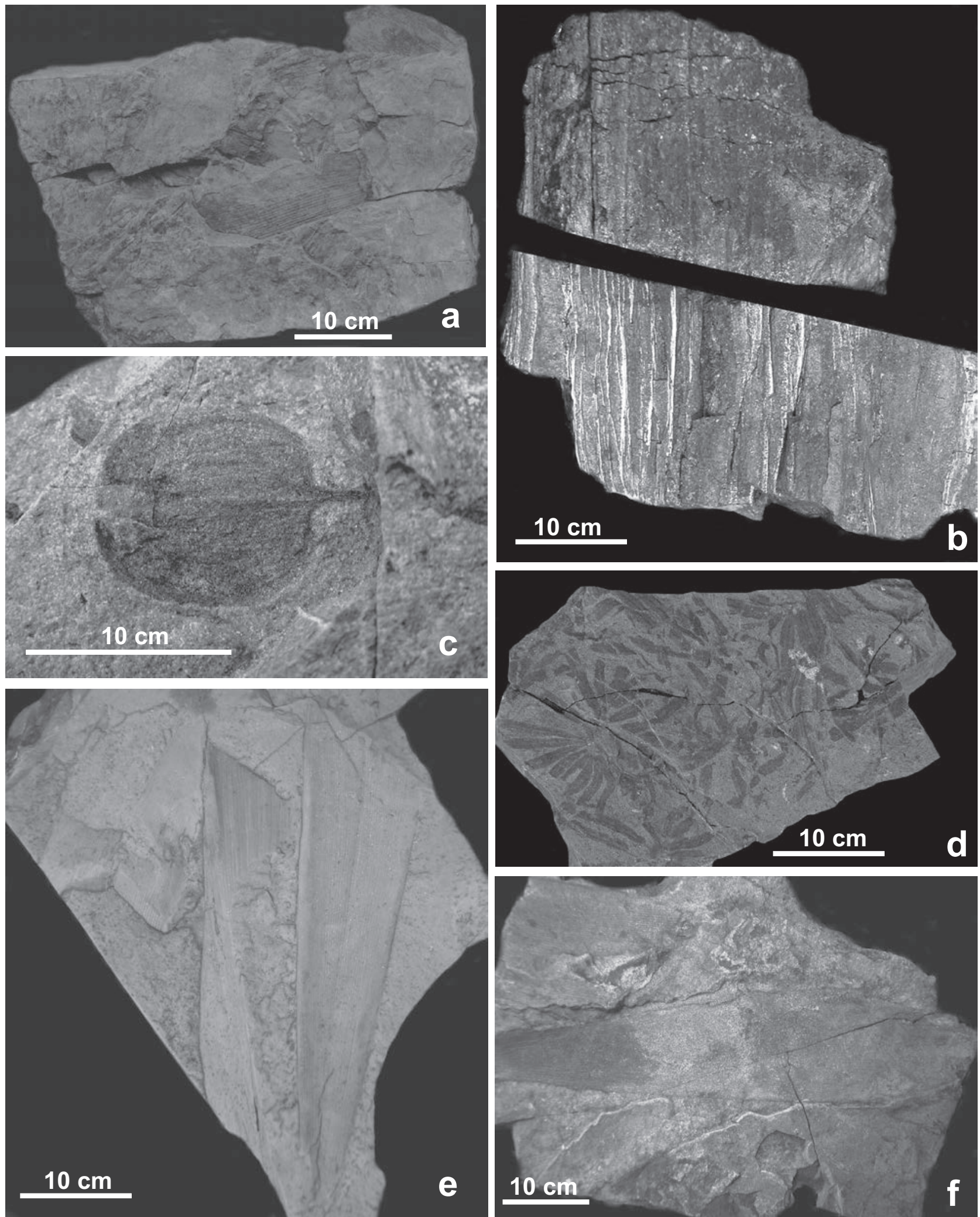

Fig. 3 Lower to Middle Permian flora gathered from studied formations. All the specimens are stored in the collections of the Czech Geological Survey: a - common remains and detritus of Early Permian flora with dominant leaves of cordaitoid Rufloria sp., Khar Argalant Fm.; b - remains of silicified cordaitoid tree wood (? cf. Rufloria), Khar Argalant Fm.; c-Cardiocarpus sp., a probable seed of cordaitoid Rufloria sp., Khar Argalant Fm.; d - remains of Annularia cf. undulata Neuburg., a horsetail typical of the Lower Permian, Khar Argalant Fm.; e - foils of the Rufloria sp., Butnaa Khudag Fm.; f - leaves of cordaitoid Rufloria sp., Butnaa Khudag Fm. 
ites. Andesite and rhyolite form angular to subangular lithic fragments up to $150 \mathrm{~cm}$ in diameter. Fragments of devitrified volcanic glass are enclosed in a fine-grained clay-rich matrix. The individual debris flows are usually inversely graded with volcanic sandstones and mudstones near the base. Tuffaceous sandstones are medium-grained rocks containing tuffaceous matrix with subangular clasts of volcanic rocks and feldspars. Mudstones are very fine-grained, clay-rich, usually strongly altered by carbonatization and sericitization.

\subsubsection{Volcanic rocks}

Trachybasalt to trachyandesite are predominant in the Khar Argalant Fm. They usually form lava flows and clinkers up to several metres thick, alternating with the layers of pyroclastic rocks. Coarse-grained porphyritic trachybasalts to trachyandesites usually occur in the central part of the lava flows, surrounded by a finegrained margin. Euhedral to subhedral phenocrysts of plagioclases and rare K-feldspars are partially replaced by secondary minerals (carbonate and/or clay minerals). The matrix is usually pilotaxitic, vitrophyric or ophitic. Volcanic glass is altered to clay minerals. Amygdales up to $1 \mathrm{~cm}$ in size are filled with quartz, carbonate and chlorite.

Rhyolites form up to $2 \mathrm{~m}$ thick lenses and dikes in the epiclastic rocks. They are mostly light grey aphanitic with vitrophyric groundmass and with alkali feldspar phenocrysts and/or alkali feldspar spherulites. The rocks are in places strongly silicified and kaolinized.

Pyroclastic flows are very common and form several meter thick layers sometimes alternating with lava flows and/or epiclastic volcanic rocks. Locally preserved unwelded to weakly welded rhyolite to trachyandesite ignimbrites contain altered glass shards exhibiting some degree of compaction. Phenocrysts of K-feldspars, plagioclases, biotites and lithic fragments (trachytes) are common in the devitrified matrix. Welded ignimbrites with a predominance of fiamme and small abundances of feldspar (Fig. 2e) and/or biotite crystals and lithic fragments are occasionally present.

\subsection{Butnaa Khudag Formation}

The Butnaa Khudag Fm. is exposed on the SE slopes of the Khar Argalant mountain range (Fig. 1a). The sedimentary rocks are preserved in a brachysyncline in the hanging wall of the Delger Khangay Fm. (Fig. 1b). The syncline axis is oriented nearly E-W and is cut by a fault in the west. The maximum thickness of conglomerates is from 800 to $1000 \mathrm{~m}$. The late Early to the early Late Permian age was determined by poorly preserved terrestrial flora. The Early/Middle Permian age was established by the finds of the leaves of cordaitoid Rufloria ? sp. (see Fig. 3e-f), and the horsetails Calamites sp.

Conglomerates with layers of tuffaceous sandstones, siltstones and marls forming a well-bedded rhythmic sequence constitute the main part of the unit. Single beds of conglomerates show the thickness up to 10 metres. The conglomerates (Fig. 2f) are matrix supported, well sorted. The well rounded clasts ranging from coarse sand to pebbles are mostly composed of acid igneous rocks (biotite to amphibole-biotite granitoids account for 19-22 vol. \%, rhyolite to trachyte lavas and ignimbrites 49-59 vol. \%, quartzite and quartz 11-6 vol. \%). Basic and intermediate volcanic clasts are usually subordinate (basalt to andesite 3-5 vol. \%) and sandstone clasts (2-7 vol. \%) are sometimes present. Layers of tuffaceous siltstones, sandstones and marlstones with thin beds of coal-bearing siltstones are exposed in the southern limb of the syncline. Within this complex are locally present layers, up to several $\mathrm{cm}$ thick, of fine-grained pyroclastic fall deposits, occasionally hyalocrystalline.

\subsection{Shar Oroy Massif}

The Shar Oroy Massif crops out as a few individual bodies inside the Khar Argalant mountain range. The largest oval exposure occurs in its eastern part. Relics of older volcano-sedimentary complexes (amphibolites, metagabbros, metavolcanic rocks, marbles and gneisses) are seen in roof pendants of the intrusion in the northern and north-eastern parts of the intrusive body. Tectonic slices (Fig. 4a) of white, medium-grained marbles up to several tens of metres thick occur along the boundary between the granites and the basalts of the Delger Khangay Fm. at the eastern margin of the body. The marble is partially silicified but lacks the minerals typical of contact metamorphism.

Granites ranging to syenite compositions are the predominant rocks in the massif and are designated as the felsic group. Mafic microdiorite enclaves (Fig. 4b) and small gabbro and diorite bodies, as subordinate, are widespread throughout the massif and are classified as the mafic group. The Shar Oroy Massif is penetrated by the basalt dikes of at least two generations. Dikes of diorite and granodiorite are rare.

The structures along the contact of the intrusive rocks with the Permian volcanic rocks of the Delger Khangay Fm. suggest cogenetic relationships between these rocks. This is documented by basalt dikes (with similar chemical composition as volcanic rocks Delger Khangay Fm.) that crosscut granite as well as rhyolite enclaves in the granite. 

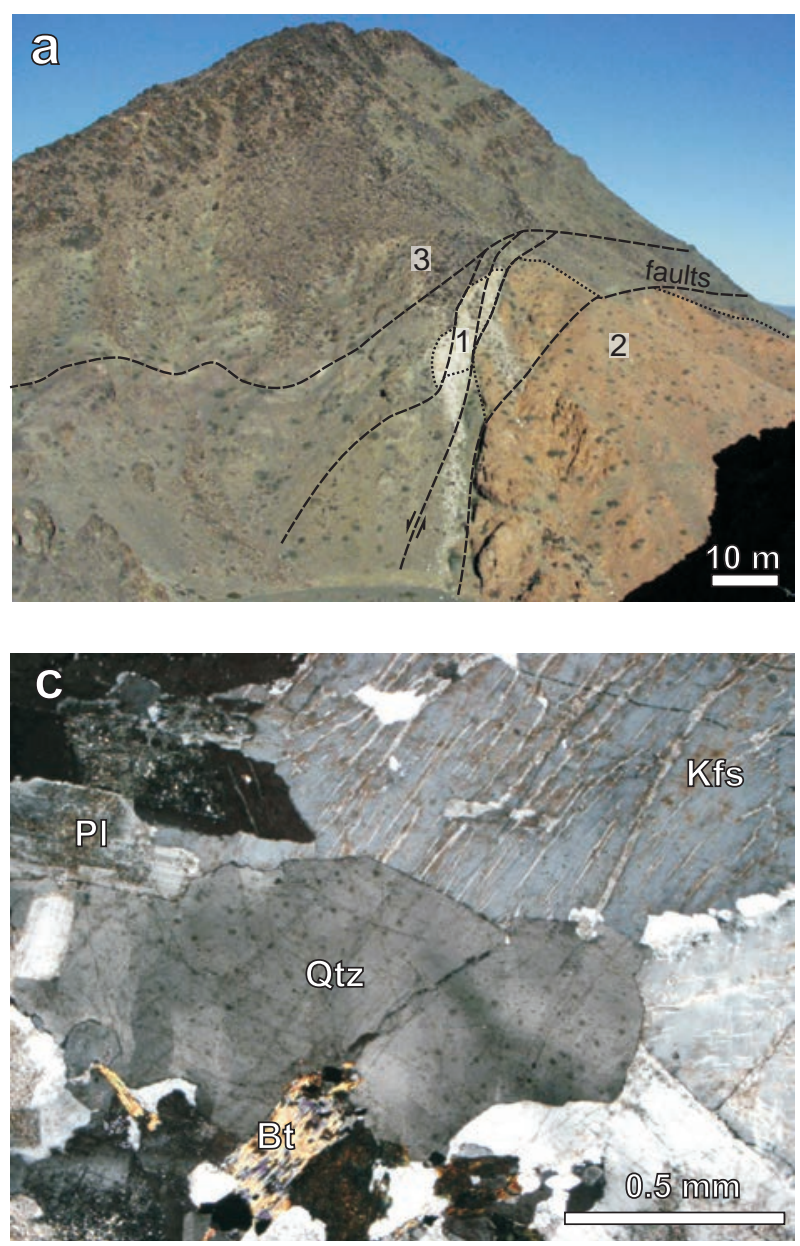
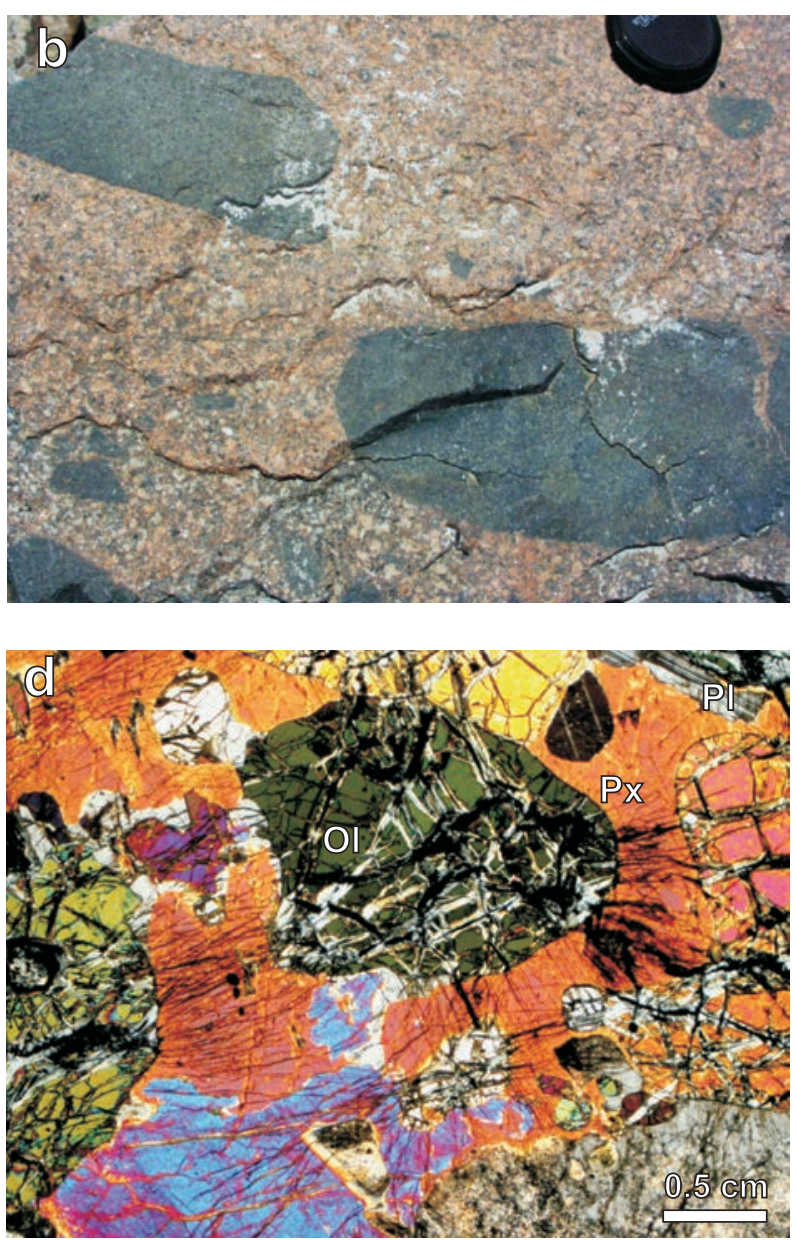

Fig. 4 Outcrop photographs and photomicrographs from the rocks of the Shar Oroy Massif: a - boudin of marbles (1) along a tectonically reworked (normal faults) contact of the massif (2) and basalts (3) of the Delger Khangay Fm.; b - mafic microgranular enclaves in the granite; $\mathbf{c}-$ granite, crossed nicols; $\mathbf{d}$ - olivine in gabbro, crossed nicols.

\subsubsection{Felsic group}

The reddish grey, medium-grained, scarcely porphyritic biotite granites predominate in the Shar Oroy Massif. The contacts with other magmatic rocks are sharp. They consist of quartz, partially chloritized biotite, sericitized and/or kaolinized plagioclase (albite to oligoclase) and alkali feldspars (Fig. 4c). Typical accessory minerals are ilmenite, apatite and zircon. Granophyric textures are sometimes preserved.

Biotite and amphibole-biotite syenite and granodiorite form smaller igneous bodies in the central and western parts of the Khar Argalant mountain range and also xenoliths in the prevailing granites of the Shar Oroy Massif. They consist of partially altered (sericitized, kaolinized) euhedral to subhedral plagioclase (albite to oligoclase) and subhedral alkali feldspar. Plagioclase displays oscillatory zoning; rarely are present resorbed cores or internal zones. The majority of samples contains less than 10 vol. $\%$ of anhedral quartz. Biotite flakes prevail over green-brown amphibole; both are partially replaced by chlorite. Amphiboles form grains of subhedral to anhedral shapes of mostly magnesiohornblende $\left(\mathrm{X}_{\mathrm{Fe}}=0.66-0.68\right.$, $\mathrm{Si}=6.88-7.08 \mathrm{apfu}$ ), locally rimmed by the needles of younger actinolite $\left(\mathrm{X}_{\mathrm{Fe}}=0.72-0.74, \mathrm{Si}=7.56-7.82 \mathrm{apfu}\right)$. Typical accessories are titanite, apatite and allanite. Epidote and clinozoisite are characteristic secondary minerals. The syenite was locally deformed along several $\mathrm{dm}$ to $\mathrm{cm}$ thick shear zones shown by deformed feldspars, recrystallization of quartz and its undulatory extinction in thin sections.

\subsubsection{Mafic group}

Amphibole diorites and pyroxene-olivine gabbros are exceptionally exposed in bodies up to $1 \mathrm{~km}$ in diameter but enclaves up to several metres across randomly distributed through the massif are relatively common. Mafic enclaves up to several metres in diameter also form ball 


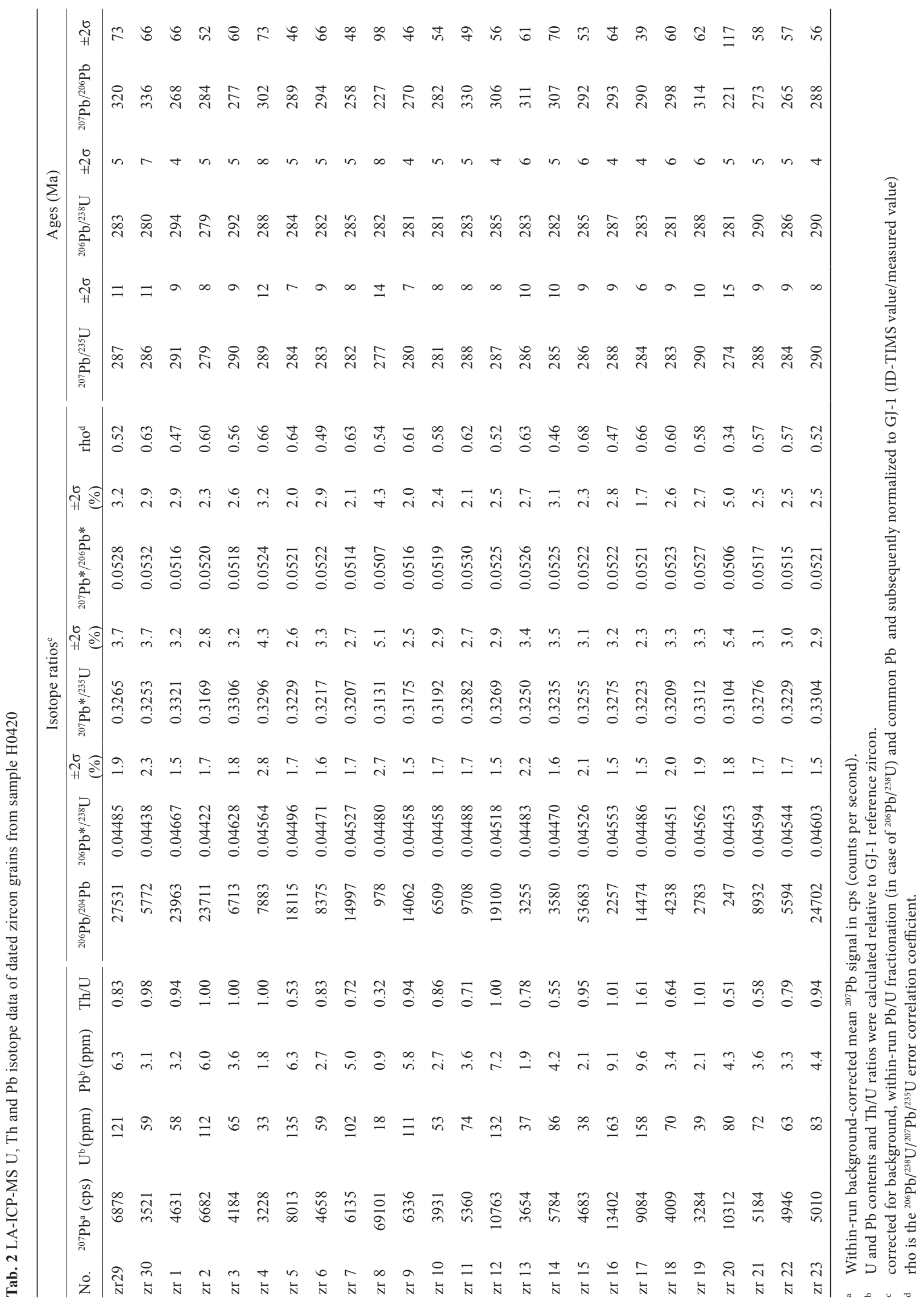



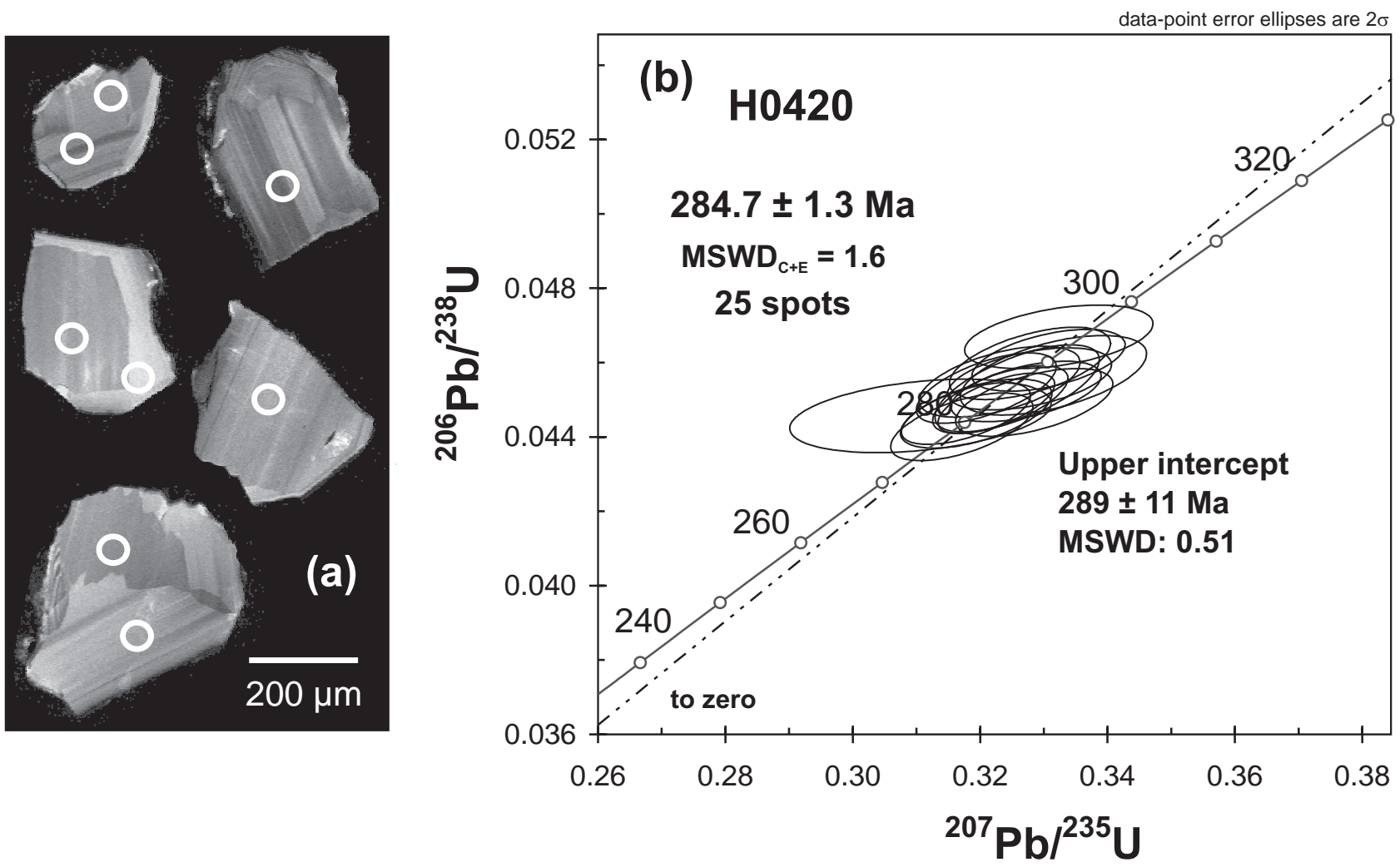

Fig. 5a - Cathodoluminescence (CL) images of dated zircons from the granite sample H0420; b - U-Pb LA-ICP-MS zircon concordia diagram.

and pillow structures in the medium- to coarse-grained granite and granodiorite (Fig. 4b). The contacts of dioritic and gabbroic (medium- to fine-grained) enclaves to the felsic matrix are sharp. Gabbros of the larger bodies are medium- to coarse-grained, dark grey rocks. They are composed of subhedral tabular crystals of plagioclase (andesine to labradorite) that exhibit more or less continuous normal zoning. They are partly saussuritized. Amphiboles form subhedral crystals. A minority of the studied samples contains clinopyroxene partly replaced by actinolite. Chloritized biotite is rare. Small grains of epidote and clinozoisite are of secondary nature. Apatite and opaque minerals are common accessories. Olivinepyroxene gabbros are rare; their olivine is partly replaced by serpentine minerals (Fig. 4d).

\section{U-Pb LA-ICP-MS zircon dating and $\mathrm{Sr}-\mathrm{Nd}$ isotopic compositions}

Biotite granite (sample H0420) is characterized by clear and colourless, short prismatic to equant zircon grains or grain fragments $200-600 \mu \mathrm{m}$ in size. The CL images display fine to coarse oscillatory zoning as well as sector zoning, and sometimes a more luminescent outer domain (Fig. 5a). The U contents are 18 to $163 \mathrm{ppm}$ and the $\mathrm{Th} / \mathrm{U}$ ratios 0.3 to 1.6. The analyses (Tab. 2) are all equivalent and concordant with ${ }^{207} \mathrm{~Pb} /{ }^{206} \mathrm{~Pb}$ age of $289 \pm 11 \mathrm{Ma}$ and concordia age of $285 \pm 1 \mathrm{Ma}$ (Fig. 5b) corresponding to Early Permian. The latter is interpreted as the best timing the granite emplacement.

The granite contains less radiogenic strontium $\left({ }^{87} \mathrm{Sr} /{ }^{86} \mathrm{Sr}_{285}=0.7043\right)$ and more radiogenic neodymium $\left(\varepsilon_{285}^{\mathrm{Nd}}=+1.3\right)$ than the syenite $\left({ }^{87} \mathrm{Sr} /{ }^{86} \mathrm{Sr}_{285}=0.7048\right.$ and $\left.\varepsilon_{285}^{\mathrm{Nd}}=+0.7\right)(\mathrm{Tab} .3)$.

Tab. $3 \mathrm{Sr}-\mathrm{Nd}$ isotopic data for the plutonic rocks of the Shar Oroy Massif

\begin{tabular}{lcc}
\hline Sample & $\begin{array}{l}\text { H0419 } \\
\text { granite }\end{array}$ & $\begin{array}{l}\text { D0372 } \\
\text { syenite }\end{array}$ \\
\hline $\mathrm{Rb}(\mathrm{ppm})$ & 227.6 & 7.2 \\
$\mathrm{Sr}(\mathrm{ppm})$ & 223.3 & 398.4 \\
$\mathrm{Rb} / \mathrm{Sr}$ & 1.0193 & 0.0181 \\
$\mathrm{Sm}(\mathrm{ppm})$ & 3.4 & 2.4 \\
$\mathrm{Nd}(\mathrm{ppm})$ & 25.6 & 11.2 \\
${ }^{87} \mathrm{Rb} /{ }^{86} \mathrm{Sr}$ & 2.95254 & 0.05229 \\
${ }^{87} \mathrm{Sr} /{ }^{86} \mathrm{Sr}$ & 0.716299 & 0.704982 \\
$2 \mathrm{s.e.} \mathrm{Sr}$ & 0.000012 & 0.000008 \\
${ }^{147} \mathrm{Sm} /{ }^{144} \mathrm{Nd}$ & 0.08029 & 0.12955 \\
${ }^{143} \mathrm{Nd} /{ }^{144} \mathrm{Nd}$ & 0.512488 & 0.512549 \\
$2 \mathrm{s.e.} \mathrm{Nd}$ & 0.000005 & 0.000006 \\
$\left({ }^{87} \mathrm{Sr} /{ }^{86} \mathrm{Sr}\right)_{285}$ & 0.704326 & 0.704770 \\
$\left({ }^{143} \mathrm{Nd} /{ }^{144} \mathrm{Nd}\right)_{285}$ & 0.512338 & 0.512307 \\
$\varepsilon_{285}^{\mathrm{Nd}}$ & 1.31 & 0.71 \\
\hline
\end{tabular}


Tab. 4 Representative whole-rock chemical analyses

\begin{tabular}{|c|c|c|c|c|c|c|c|c|c|c|}
\hline $\begin{array}{l}\text { Sample No. } \\
\text { Rock }\end{array}$ & $\begin{array}{l}\text { H0748 } \\
\text { rhyolite }\end{array}$ & $\begin{array}{c}\text { D0470 } \\
\text { trachyte }\end{array}$ & $\begin{array}{c}\text { H1052 } \\
\text { basalt }\end{array}$ & $\begin{array}{l}\text { H0935 } \\
\text { trachyte }\end{array}$ & $\begin{array}{c}\text { H0207B } \\
\text { basalt }\end{array}$ & $\begin{array}{c}\mathrm{H} 0422 \\
\text { basalt }\end{array}$ & $\begin{array}{c}\text { D0354b } \\
\text { monzonite }\end{array}$ & $\begin{array}{c}\text { D0378a-2 } \\
\text { granite }\end{array}$ & $\begin{array}{l}\text { D0433 } \\
\text { granite }\end{array}$ & $\begin{array}{l}\text { D0353 } \\
\text { gabbro }\end{array}$ \\
\hline \multicolumn{11}{|l|}{ wt. \% } \\
\hline $\mathrm{SiO}_{2}$ & 74.29 & 67.15 & 49.51 & 67.00 & 49.12 & 43.98 & 61.07 & 76.26 & 71.74 & 50.06 \\
\hline $\mathrm{TiO}_{2}$ & 0.32 & 0.59 & 1.81 & 0.66 & 1.68 & 1.61 & 0.73 & 0.10 & 0.31 & 1.29 \\
\hline $\mathrm{Al}_{2} \mathrm{O}_{3}$ & 13.24 & 15.30 & 16.39 & 15.76 & 17.16 & 17.96 & 18.03 & 12.63 & 14.04 & 16.08 \\
\hline $\mathrm{Fe}_{2} \mathrm{O}_{3 \text { tot }}$ & 3.56 & 3.50 & 10.23 & 3.33 & 10.33 & 12.78 & 3.77 & 1.42 & 2.73 & 9.41 \\
\hline $\mathrm{MnO}$ & 0.04 & 0.09 & 0.15 & 0.10 & 0.13 & 0.11 & 0.08 & 0.06 & 0.05 & 0.13 \\
\hline $\mathrm{Cr}_{2} \mathrm{O}_{3}$ & 0.00 & 0.00 & 0.02 & 0.00 & 0.01 & 0.01 & 0.00 & 0.00 & 0.00 & 0.03 \\
\hline $\mathrm{MgO}$ & 0.36 & 0.38 & 5.68 & 0.45 & 3.71 & 6.27 & 1.15 & 0.10 & 0.42 & 5.98 \\
\hline $\mathrm{CaO}$ & 0.13 & 0.57 & 7.49 & 0.74 & 8.50 & 12.27 & 2.00 & 0.51 & 1.15 & 9.57 \\
\hline $\mathrm{Na}_{2} \mathrm{O}$ & 4.00 & 5.60 & 3.92 & 5.46 & 3.52 & 2.40 & 5.67 & 3.80 & 3.83 & 3.23 \\
\hline $\mathrm{K}_{2} \mathrm{O}$ & 3.06 & 5.55 & 1.59 & 5.13 & 2.12 & 0.42 & 5.30 & 4.87 & 4.95 & 1.73 \\
\hline $\mathrm{P}_{2} \mathrm{O}_{5}$ & 0.04 & 0.10 & 0.64 & 0.13 & 0.88 & 0.20 & 0.16 & 0.02 & 0.09 & 0.49 \\
\hline LOI & 0.9 & 0.9 & 2.3 & 1.1 & 2.5 & 1.3 & 1.6 & 0.1 & 0.6 & 1.8 \\
\hline SUM & 99.94 & 99.73 & 99.73 & 99.86 & 99.66 & 99.31 & 99.56 & 99.87 & 99.91 & 99.8 \\
\hline \multicolumn{11}{|l|}{ ppm } \\
\hline $\mathrm{Ba}$ & 311.5 & 181.3 & 826.9 & 438.4 & 765.0 & 199.3 & 1386.7 & 176.6 & 530.2 & 405.4 \\
\hline $\mathrm{Co}$ & 2.3 & 2.4 & 31.0 & 1.6 & 30.3 & 47.1 & 5.1 & 1.1 & 3.4 & 28.6 \\
\hline $\mathrm{Cu}$ & 21.3 & 8.6 & 50.1 & 4.8 & 42.9 & 132.0 & 8.4 & 15.9 & 11.9 & 84.9 \\
\hline $\mathrm{Ni}$ & 5.7 & 5.0 & 48.9 & 4.5 & 53.8 & 28.4 & 13.4 & 3.5 & 4.5 & 45.6 \\
\hline $\mathrm{Rb}$ & 60.0 & 125.7 & 28.0 & 99.3 & 43.6 & 5.4 & 53.3 & 194.6 & 184.8 & 30.5 \\
\hline $\mathrm{Sr}$ & 119.1 & 49.1 & 934.5 & 76.0 & 1185.4 & 1281.9 & 518.3 & 55.0 & 270.2 & 1134.1 \\
\hline V & 12 & 26 & 214 & 13 & 194 & 467 & 44 & 5 & 23 & 208 \\
\hline $\mathrm{Sn}$ & 2 & 4 & 1 & 3 & 1 & $<1$ & 1 & 2 & 2 & 1 \\
\hline $\mathrm{Zn}$ & 18 & 52 & 71 & 98 & 89 & 21 & 32 & 21 & 25 & 26 \\
\hline As & 2.7 & 0.8 & 3.3 & 2.6 & 0.7 & $<0.5$ & 0.8 & 0.8 & 2.2 & 1.6 \\
\hline $\mathrm{U}$ & 4.1 & 3.7 & 0.8 & 3.2 & 0.8 & 0.2 & 1.4 & 2.8 & 5.8 & 1.4 \\
\hline $\mathrm{Nb}$ & 19.7 & 34.6 & 10.7 & 28.6 & 16.8 & 1.7 & 7.6 & 10.3 & 11.8 & 6.5 \\
\hline Mo & 1.0 & 1.9 & 1.1 & 0.4 & 0.5 & 0.1 & 0.3 & 0.5 & 0.7 & 0.5 \\
\hline $\mathrm{Y}$ & 41.2 & 69.5 & 27.8 & 60.2 & 28.3 & 15.9 & 18.8 & 8.1 & 20.3 & 23.7 \\
\hline $\mathrm{Zr}$ & 404.2 & 737.8 & 177.4 & 686.5 & 182.6 & 42.8 & 631.9 & 75.1 & 237.1 & 131.2 \\
\hline $\mathrm{Pb}$ & 21.8 & 27.6 & 5.7 & 26.4 & 6.2 & 1.0 & 9.0 & 9.9 & 8.9 & 4.9 \\
\hline $\mathrm{Cd}$ & 0.1 & 0.3 & 0.1 & 0.2 & 0.1 & $<0.1$ & $<0.1$ & 0.1 & $<0.1$ & 0.1 \\
\hline Cs & 1.9 & 0.7 & 1.1 & 0.8 & 1.2 & 0.4 & 0.7 & 4.4 & 3.2 & 1.0 \\
\hline Th & 13.7 & 14.6 & 2.5 & 12.8 & 3.4 & 0.5 & 5.2 & 26.7 & 31.3 & 6.4 \\
\hline $\mathrm{Ta}$ & 1.2 & 2.4 & 0.6 & 1.8 & 0.9 & $<0.1$ & 0.4 & 0.8 & 1.3 & 0.5 \\
\hline Hf & 10.8 & 18.5 & 4.8 & 16.1 & 4.7 & 1.3 & 13.5 & 3.0 & 8.1 & 4.3 \\
\hline $\mathrm{Sc}$ & 7 & 5 & 22 & 6 & 20 & 38 & 6 & 2 & 3 & 28 \\
\hline $\mathrm{Sb}$ & 0.1 & 0.2 & $<0.1$ & 0.3 & 0.1 & $<0.1$ & 0.1 & 0.2 & 0.1 & 0.1 \\
\hline W & 1.2 & 0.8 & 3.3 & 2.3 & 0.2 & 0.1 & 0.4 & 0.7 & 0.7 & 0.9 \\
\hline $\mathrm{Ga}$ & 17.3 & 26.1 & 19.0 & 23.8 & 24.8 & 23.6 & 17.4 & 15.6 & 15.9 & 17.3 \\
\hline $\mathrm{Be}$ & 2 & 5 & 1 & 6 & 1 & 1 & 1 & 2 & 3 & 1 \\
\hline $\mathrm{La}$ & 54.9 & 98.4 & 35.5 & 82.4 & 42.9 & 8.7 & 42.2 & 23.1 & 44.2 & 33.6 \\
\hline $\mathrm{Ce}$ & 118.1 & 214.1 & 82.8 & 175.0 & 92.1 & 23.1 & 81.2 & 42.5 & 84.8 & 69.8 \\
\hline $\operatorname{Pr}$ & 13.23 & 23.91 & 9.90 & 19.15 & 10.73 & 3.19 & 9.33 & 3.69 & 9.12 & 8.36 \\
\hline $\mathrm{Nd}$ & 48.6 & 76.2 & 38.5 & 70.8 & 47.7 & 16.0 & 34.3 & 10.2 & 28.5 & 31.7 \\
\hline $\mathrm{Sm}$ & 9.6 & 13.4 & 7.9 & 12.1 & 8.9 & 3.7 & 5.7 & 1.4 & 4.9 & 6.4 \\
\hline $\mathrm{Eu}$ & 0.82 & 1.25 & 2.42 & 1.79 & 2.38 & 1.31 & 2.04 & 0.19 & 0.63 & 1.78 \\
\hline $\mathrm{Gd}$ & 7.17 & 9.67 & 6.66 & 9.36 & 7.29 & 3.70 & 4.16 & 1.02 & 3.46 & 5.21 \\
\hline $\mathrm{Tb}$ & 1.17 & 1.88 & 0.99 & 1.59 & 1.00 & 0.49 & 0.72 & 0.18 & 0.56 & 0.83 \\
\hline Dy & 6.79 & 10.54 & 4.93 & 9.95 & 5.23 & 3.15 & 3.48 & 1.12 & 2.99 & 3.95 \\
\hline Ho & 1.43 & 2.39 & 0.96 & 2.09 & 1.01 & 0.57 & 0.69 & 0.25 & 0.63 & 0.84 \\
\hline $\mathrm{Er}$ & 4.24 & 7.07 & 2.73 & 6.13 & 2.46 & 1.41 & 1.87 & 0.89 & 2.02 & 2.20 \\
\hline $\mathrm{Tm}$ & 0.64 & 1.23 & 0.39 & 1.01 & 0.32 & 0.18 & 0.28 & 0.15 & 0.31 & 0.35 \\
\hline $\mathrm{Yb}$ & 4.36 & 7.61 & 2.36 & 6.05 & 2.22 & 1.23 & 2.00 & 1.31 & 2.61 & 2.12 \\
\hline $\mathrm{Lu}$ & 0.63 & 1.21 & 0.38 & 1.09 & 0.33 & 0.16 & 0.30 & 0.20 & 0.41 & 0.36 \\
\hline $\mathrm{A} / \mathrm{CNK}$ & 1.31 & 0.94 & 0.75 & 0.99 & 0.73 & 0.72 & 0.96 & 1.01 & 1.02 & 0.65 \\
\hline $\mathrm{K}_{2} \mathrm{O} / \mathrm{Na}_{2} \mathrm{O}$ & 0.77 & 0.99 & 0.41 & 0.94 & 0.60 & 0.18 & 0.93 & 1.28 & 1.29 & 0.54 \\
\hline $\mathrm{Eu} / \mathrm{Eu}^{*}$ & 0.30 & 0.34 & 1.02 & 0.51 & 0.90 & 1.07 & 1.28 & 0.49 & 0.47 & 0.94 \\
\hline $\mathrm{La}_{\mathrm{N}} / \mathrm{Yb}_{\mathrm{N}}$ & 8.49 & 8.72 & 10.14 & 9.18 & 13.03 & 10.73 & 14.23 & 11.89 & 11.42 & 10.69 \\
\hline Sum REE & 271.7 & 468.9 & 196.4 & 398.5 & 224.6 & 177.1 & 188.3 & 86.2 & 185.1 & 167.5 \\
\hline
\end{tabular}




\section{Geochemistry}

\subsection{Volcanic rocks}

The whole-rock chemical compositions (Tab. 4) of the Permian volcanic rocks from the Khar Argalant and Delger Khangay formations exhibit many similarities. They have typical high variability of $\mathrm{K}_{2} \mathrm{O}(0.4-6.3$ wt. \%), with $\mathrm{K}_{2} \mathrm{O} / \mathrm{Na}_{2} \mathrm{O}$ ratios ranging between 0.2 and 1.6. The rocks plot close to the boundary between the subalkaline and alkaline associations (Irvine and Baragar 1971) and can be subdivided into two groups based on the TAS (Le Bas et al. 1986) classification (Fig. 6a).

The first group (mafic volcanic rocks containing $\mathrm{SiO}_{2}$ between 44 to $58 \mathrm{wt}$. \%) correspond to basalts, trachybasalts, basaltic trachyandesites, basaltic andesites, trachyandesites; the second group (silica-rich felsic igneous rocks, 59-80 wt. \% $\mathrm{SiO}_{2}$ ) includes predominantly trachytes, trachyandesites and rhyolites.

In the Harker diagrams, the rocks of the first group exhibit negative correlations of $\mathrm{SiO}_{2}$ with $\mathrm{TiO}_{2}, \mathrm{FeO}_{\text {tot }}$, $\mathrm{MgO}$ and $\mathrm{CaO}$, and positive one with the $\mathrm{Na}_{2} \mathrm{O}$ contents (Fig. 7). The REE patterns are very similar for the rocks of the Delger Khangay and Khar Argalant formations. They are enriched in LREE $\left(\mathrm{La}_{\mathrm{N}} / \mathrm{Yb}_{\mathrm{N}}=4.8\right.$ to 13.4$)$, with small negative or positive Eu anomalies $\left(\mathrm{Eu} / \mathrm{Eu}^{*}=\right.$ 0.7-1.1, Fig. 8). The primitive-mantle normalized spidergram (Sun and McDonough 1989, Fig. 9) indicates slight enrichment in large-ion lithophile elements (LILE; e.g. $\mathrm{Cs}, \mathrm{K}, \mathrm{Ba}, \mathrm{Pb}$ ) and relatively low content of $\mathrm{Nb}$ in the mafic group.

Rocks of the second - felsic group are metaluminous to peraluminous $(\mathrm{A} / \mathrm{CNK}=0.88-1.44)$. Variation diagrams indicate linear negative correlations of $\mathrm{SiO}_{2}$ with $\mathrm{TiO}_{2}, \mathrm{Al}_{2} \mathrm{O}_{3}, \mathrm{FeO}_{\text {tot }}, \mathrm{Na}_{2} \mathrm{O}, \mathrm{Ba}$, and a positive correlation with $\mathrm{Rb}$ (Fig. 7). Wide ranges of $\mathrm{Al}_{2} \mathrm{O}_{3}(10.8-17.0$ wt. \%), $\mathrm{K}_{2} \mathrm{O}\left(1.4-6.3\right.$ wt. \%) and $\mathrm{Na}_{2} \mathrm{O}(2.9-6.8$ wt. \%) are characteristic. Chondrite-normalized REE patterns (Fig. 8) are relatively flat in the HREE and enriched in LREE $\left(\mathrm{La}_{\mathrm{N}} / \mathrm{Yb}_{\mathrm{N}}=3.2-14.6\right)$. Trachytes and rhyolites of the Khar Argalant Fm. are characterized by variously developed negative Eu anomalies $\left(\mathrm{Eu} / \mathrm{Eu}^{*}=0.1-0.9\right)$, in general deeper than in the Delger Khangay Formation $\left(\mathrm{Eu} / \mathrm{Eu}^{*}=\right.$ 0.3-1.0). Rocks of the felsic group are enriched in LILE (mainly $\mathrm{Rb}$ and $\mathrm{K}$ ), Th, $\mathrm{U}$ and REE and depleted in $\mathrm{Sr}$ and Ti compared with the bulk continental crust (Fig. 10, Taylor and McLennan 1995).

The chemical composition of the dikes cutting the Shar Oroy Massif is similar to that of the volcanic rocks (Fig. 7).

Rhyolites have mainly intraplate or post-collisional characteristics (Fig. 6b) according to the classification of Pearce et al. (1984) and Pearce (1996). Basic rocks can be classified in the discrimination diagram of Pearce and Norry (1979) as within-plate basalts (Fig. 6c). They correspond to calc-alkaline basalts (Fig. 6d), showing the characteristic continental fingerprint in the Th-Hf/3-Ta diagram (Wood 1980).

\subsection{Intrusive rocks}

Major- and trace-element analyses are given in Tab. 4. Two petrographical suites can be distinguished according to $\mathrm{SiO}_{2}$ abundance: basic to intermediate rocks (mafic group) with $\mathrm{SiO}_{2}$ contents between $47-57$ wt. \%, and intermediate to acid rocks of the felsic group (60-76 wt. \%). The samples plot in the gabbro, syenite and granite fields in the TAS classification diagram (Fig. 6e; Middlemost 1994). The rocks are mostly subalkaline, generally with elevated $\mathrm{K}_{2} \mathrm{O}$ contents in both the felsic (3.8-5.3 wt. \%) and mafic (1.0-2.2 wt. \%) groups. The granites are subaluminous $(\mathrm{A} / \mathrm{CNK}=1.01-1.04)$, while the more basic types are metaluminous $(\mathrm{A} / \mathrm{CNK}$ $=0.65-0.96)$. In the variation diagrams, the rocks of the felsic group exhibit negative correlations of $\mathrm{SiO}_{2}$ with $\mathrm{TiO}_{2}, \mathrm{Al}_{2} \mathrm{O}_{3}, \mathrm{FeO}_{\text {tot }}, \mathrm{MgO}$ and $\mathrm{Ba}$ and a positive correlation with $\mathrm{Rb}$ contents (Fig. 7). Trace-element signatures, according to Pearce et al. (1984) and Pearce (1996), indicate a post-collisional character of the granitoids (Fig. 6b). Chondrite-normalized REE patterns (Boynton 1984; Fig. 8) exhibit LREE fractionation $\left(\mathrm{La}_{\mathrm{N}} / \mathrm{Yb}_{\mathrm{N}}=\right.$ $7-20)$. Syenite samples $\left(\mathrm{Eu} / \mathrm{Eu}^{*}=1.3-1.8\right)$ and most of diorites to gabbros $\left(\mathrm{Eu} / \mathrm{Eu}^{*}=0.9-1.2\right)$ display positive or weak negative Eu anomalies in contrast to sizeable negative $\mathrm{Eu}$ anomalies of granites $\left(\mathrm{Eu} / \mathrm{Eu}^{*}=0.5-0.8\right)$. The $\mathrm{Rb} / \mathrm{Sr}$ ratios range between 0.29 and 3.54 for the granite, 0.06-0.11 for the syenite and 0.03-0.04 for the diorite up to gabbro. In the primitive-mantle normalized spidergram (Fig. 9), the mafic plutonic rocks exhibit patterns very similar to those of volcanic rocks. Felsic plutonic rocks are depleted in Ti and also show $\mathrm{Nb}$, Ta, HREE and Y contents lower than the bulk continental crust (Taylor and McLennan 1995) (Fig. 10). Felsic plutonic samples from Shar Oroy Massif contain less LILE and HFSE than the felsic volcanic rocks (Fig. 10). In general, relative LILE enrichments and troughs in $\mathrm{Nb}, \mathrm{Ta}, \mathrm{Sr}$, and Ti characterize patterns for both groups.

\section{Discussion}

\subsection{Magmatic evolution of volcanic and plu- tonic rocks}

Volcanic rocks of the Khar Argalant and Delger Khangay formations as well as plutonic rocks of the Shar Oroy Massif are very similar in terms of their chemical compositions (Figs 7, 9). Multi-element primitive-mantle 

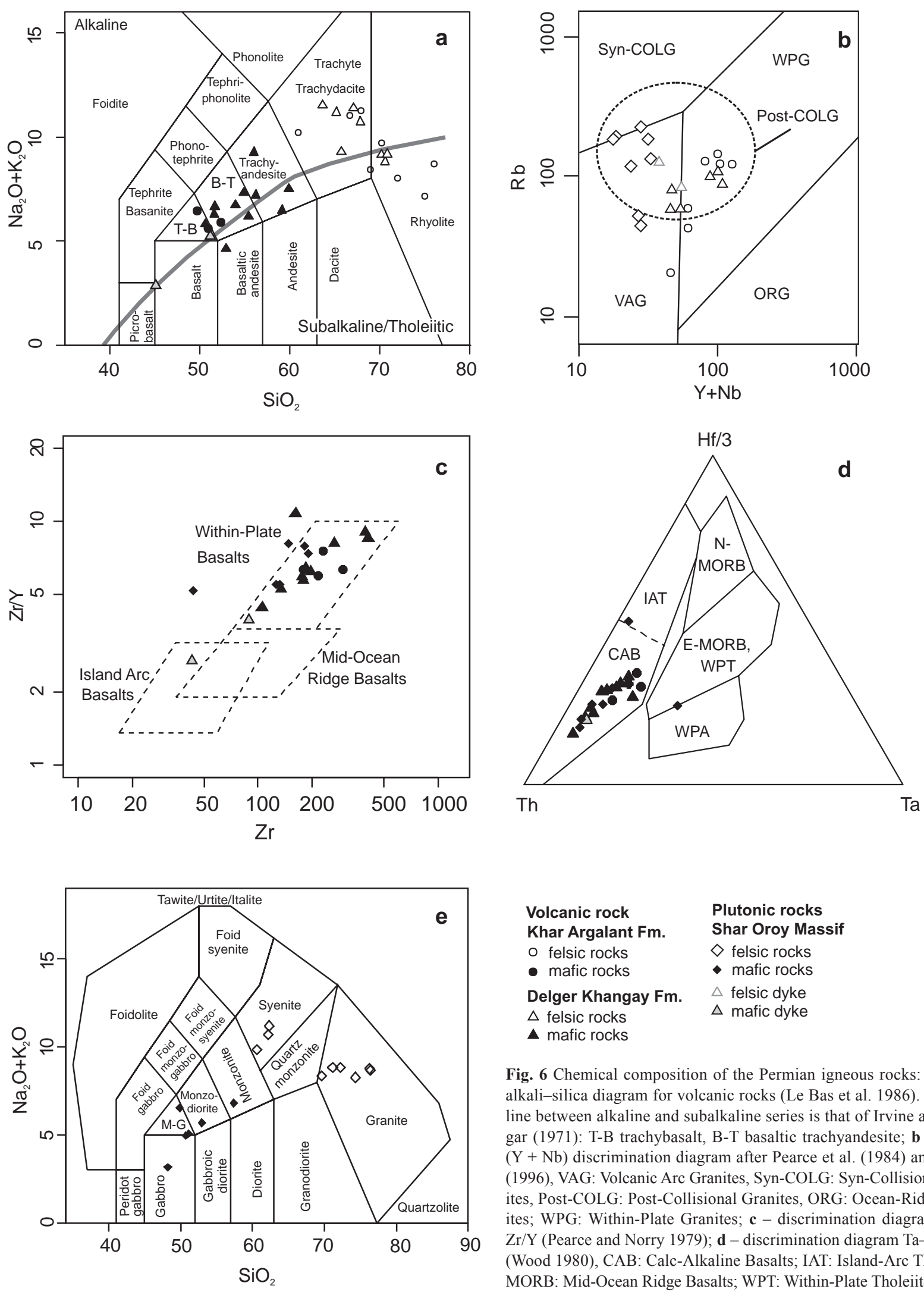
Volcanic rock
Plutonic rocks
Khar Argalant Fm.
o felsic rocks
Shar Oroy Massif
- mafic rocks
$\diamond$ felsic rocks
Delger Khangay Fm.
$\Delta$ felsic rocks
- mafic rocks
$\Delta$ felsic dyke
$\Delta$ mafic dyke

$\Delta$ mafic rocks

Fig. 6 Chemical composition of the Permian igneous rocks: a - total alkali-silica diagram for volcanic rocks (Le Bas et al. 1986). Dividing line between alkaline and subalkaline series is that of Irvine and Baragar (1971): T-B trachybasalt, B-T basaltic trachyandesite; $\mathbf{b}-\mathrm{Rb}$ vs. $(\mathrm{Y}+\mathrm{Nb})$ discrimination diagram after Pearce et al. (1984) and Pearce (1996), VAG: Volcanic Arc Granites, Syn-COLG: Syn-Collisional Granites, Post-COLG: Post-Collisional Granites, ORG: Ocean-Ridge Granites; WPG: Within-Plate Granites; $\mathbf{c}$ - discrimination diagram $\mathrm{Zr}$ vs. $\mathrm{Zr} / \mathrm{Y}$ (Pearce and Norry 1979); $\mathbf{d}$ - discrimination diagram Ta-Th-Hf/3 (Wood 1980), CAB: Calc-Alkaline Basalts; IAT: Island-Arc Tholeiites; MORB: Mid-Ocean Ridge Basalts; WPT: Within-Plate Tholeiites; WPA: Within-Plate Alkali Basalts; e - total alkali-silica diagram for plutonic rocks (Middlemost 1994): M-G monzogabbro. 

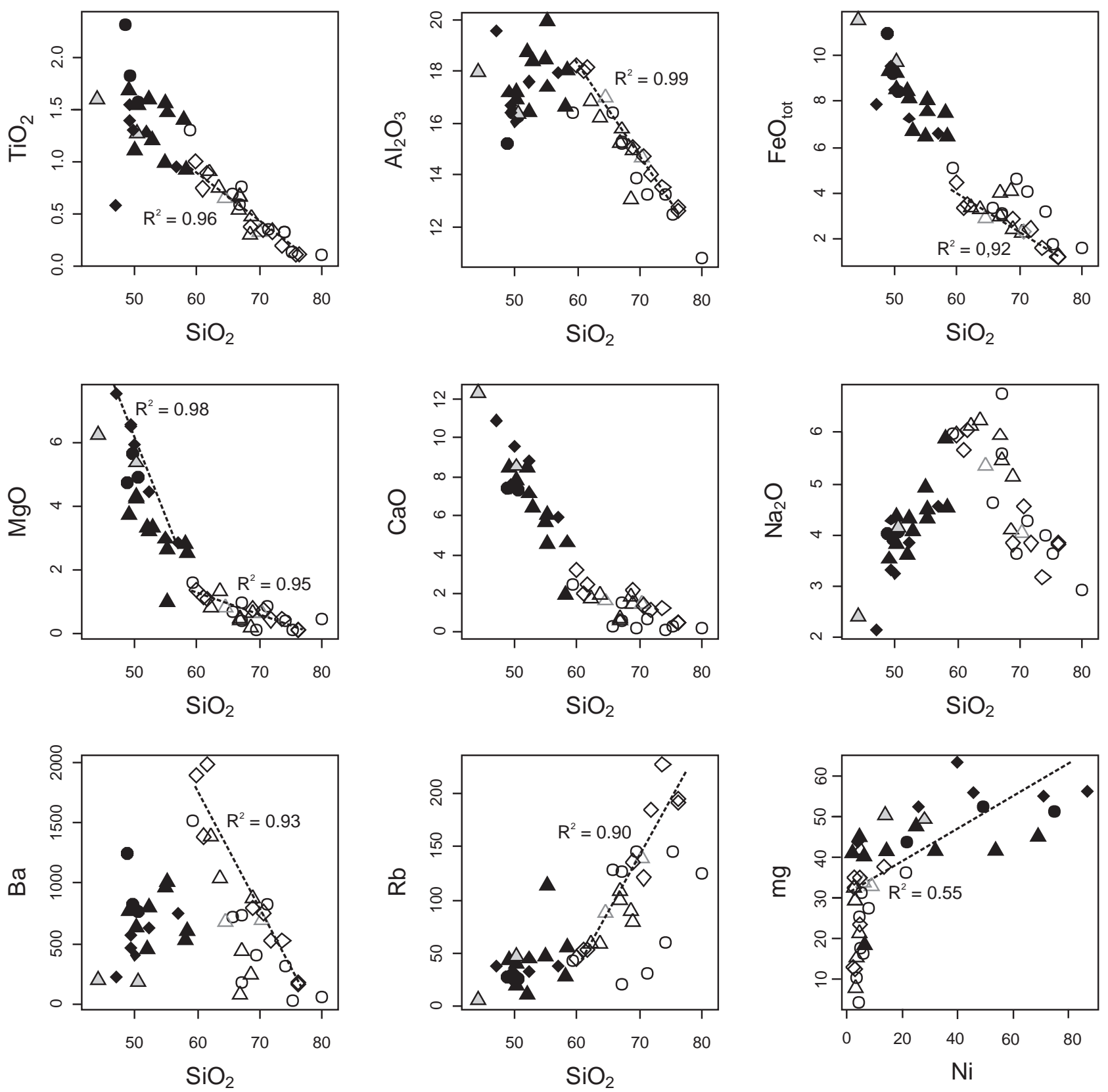

Volcanic rock Khar Argalant Fm.

Volcanic rock Delger Khangay Fm.

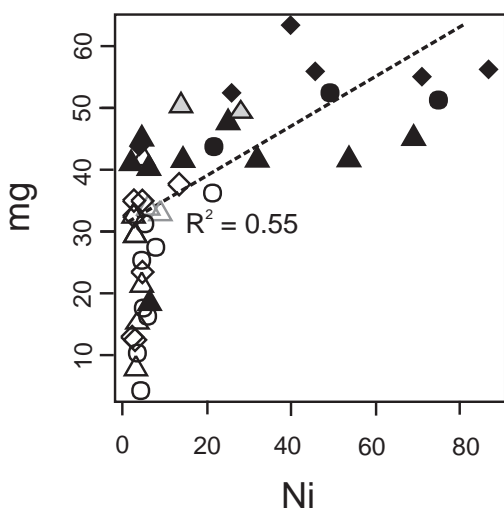

O felsic rocks

- mafic rocks

$\Delta$ felsic rocks

- mafic rocks

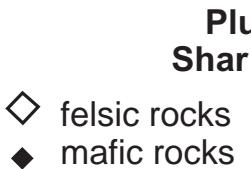

Plutonic rocks

Shar Oroy Massif

Fig. 7 Variation diagrams of silica versus selected major or trace elements and Ni versus mg-number in magmatic rocks (dashed lines - fractionation or mixing trends for felsic and/or mafic rocks of Shar Oroy Massif).

normalized spider boxplots show negative $\mathrm{Nb}$, positive $\mathrm{Pb}$ anomalies and other features characteristic of all types of mafic igneous rocks, indicating probably analogous sources and evolutions of the parental magmas (Fig. 9). The basic rocks have $\mathrm{Nb} / \mathrm{U}$ ratios of $2-21$, i.e. close to the continental crust but lower than MORB or OIB (Fig. 11a). Low $\mathrm{Nb}$ contents are typical of many continental flood basalts (Arndt and Christensen 1992). High La/Nb and low La/Ba (Fig. 11b) are comparable with compositions of basic volcanites given by Zhang et al. (2008, 2011), which were interpreted as a product of partial melting of metasomatized asthenospheric mantle in a post-collisional extensional regime (Zhang et al. 2011). Relatively flat REE patterns and HFSE depletion in the 


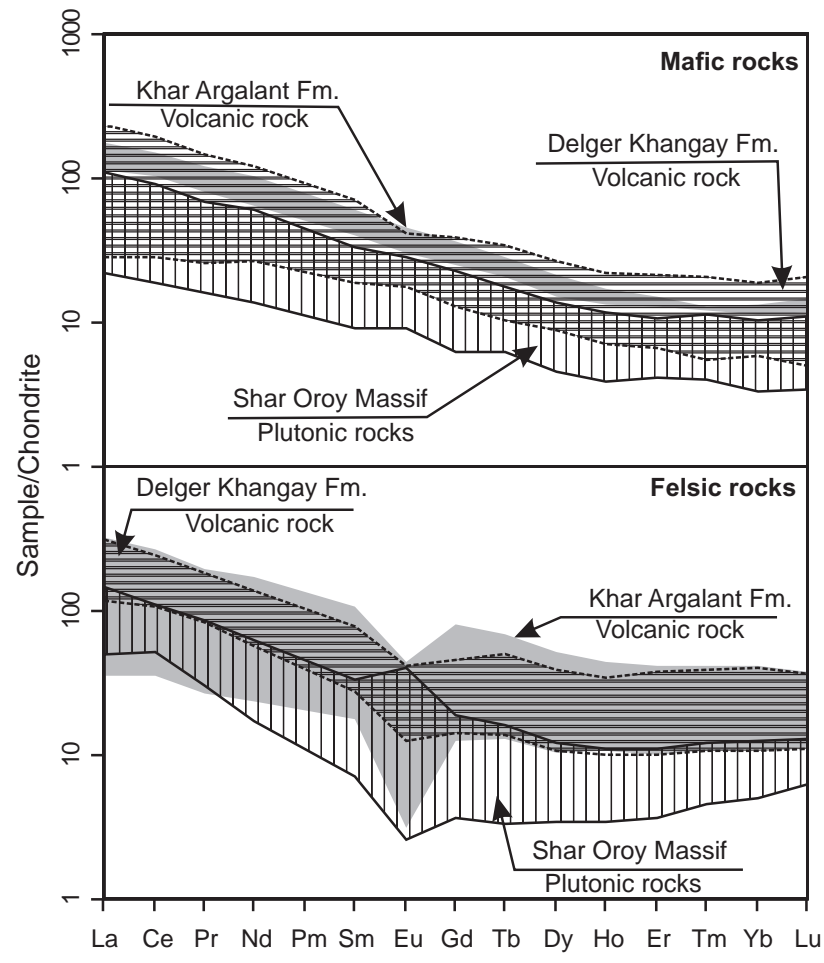

Fig. 8 Chondrite-normalized REE diagrams (Boynton 1984) for felsic and mafic rock groups.

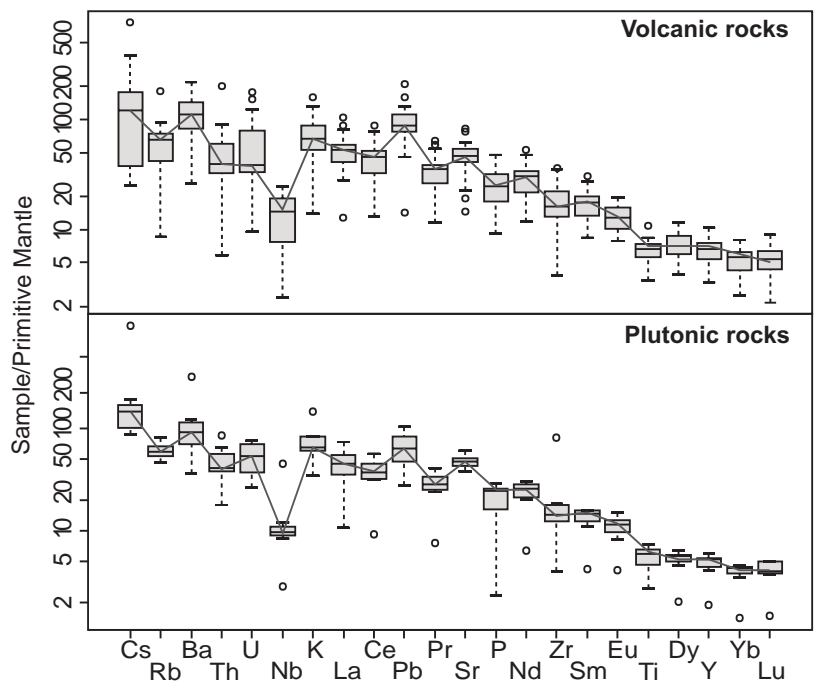

Fig. 9 Comparison of trace-element contents in mafic volcanic (Delger Khangay and Khar Argalant formations) and plutonic rocks (Shar Oroy Massif) using spider box-plot diagrams (Janoušek et al. 2004b; normalization according to Sun and McDonough 1989).

studied mafic rocks indicate high degrees of partial melting of an asthenospheric mantle (e. g. Zhou et al. 2004).

The basalts contain phenocrysts of amphibole, plagioclase, clinopyroxene and sometimes olivine (or pseudomorphs after this mineral) significant for constraining the fractional crystallization of the parental mantle melts. Negative correlations of $\mathrm{SiO}_{2}$ with $\mathrm{MgO}, \mathrm{Ni}$ and $\mathrm{CaO}$

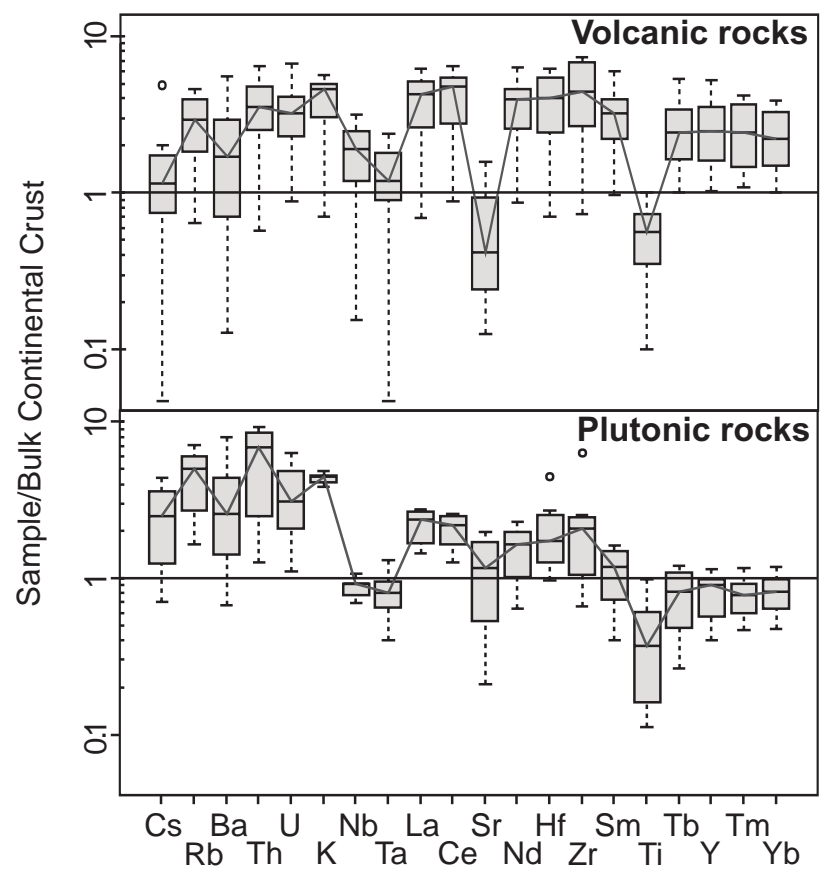

Fig. 10 Comparison of trace-element contents in felsic volcanic (Delger Khangay and Khar Argalant formations) and plutonic rocks (Shar Oroy Massif) using spider box-plot diagrams (normalization according to Taylor and McLennan 1995).

(Figs 7, 11c) in basic rocks of the Shar Oroy Massif (predominantly amphibole gabbros and diorites) can be explained by amphibole and/or clinopyroxene fractionation (locally also olivine).

Some rhyolites and trachytes display A-type geochemical characteristics, with characteristic enrichment in $\mathrm{Ga}, \mathrm{Zr}, \mathrm{Nb}, \mathrm{Ce}$ and $\mathrm{Y}(1000 \times \mathrm{Ga} / \mathrm{Al}>3, \mathrm{Nb}>20, \mathrm{Ce}$ $>100, \mathrm{Zr}>300$; Whalen et al. 1987). Syenite samples also have high $\mathrm{Zr}$ contents (240-805 ppm; Fig. 11d) and elevated Ce (81-90 ppm) with Ga (17-20 ppm). But on the other hand, most of granite and rhyolite samples show igneous-arc signatures such as low abundances of $\mathrm{Y}+\mathrm{Nb}$ (Pearce et al. 1984; Fig. 10). Such ambiguious

Fig. 11 Selected whole-rock geochemical diagrams for the studied magmatic rocks. a - Binary plot $\mathrm{Ce} / \mathrm{Pb}$ vs. $\mathrm{Nb} / \mathrm{U}$. b - Binary plot La/ Ba vs. La/Nb. Data sources: OIB and MORB after Sun and McDonough (1989), upper and lower continental crust (UCC and LCC) after Rudnick and Gao (2003). c - Binary plot log (Ni) vs. $\mathrm{SiO}_{2}$. d - Binary plot $\log (\mathrm{Rb} / \mathrm{Sr})$ vs. $\log (\mathrm{Sr})$; the up to $45 \%$ fractional crystallization trend for felsic rocks was modelled with $\mathrm{r}=0.2$ in $5 \%$ increments (fractionating assemblage of $60 \% \mathrm{Ab}$ and $40 \% \mathrm{Kfs}$ ); the dashed line represents a simple magma mixing trend calculated using chemical compositions of a gabbroic enclave (H1182b) and its host granite (H1182a). e - CIPW normative $\mathrm{Ab}-\mathrm{Or}-\mathrm{Qtz}$ triangle; lines and grey squares are respectively cotectic lines and eutectic minima at 1,2,5 and $10 \mathrm{kbar}$ for granitic melt under $\mathrm{H}_{2} \mathrm{O}$-saturated conditions (Johannes and Holtz 1996). $\mathbf{f}-\varepsilon_{\mathrm{i}}^{\mathrm{Nd}}$ vs. ${ }^{87} \mathrm{Sr} r{ }^{86} \mathrm{Sr}_{\mathrm{i}}$ plot for the Permian magmatic rocks from the Shar Oroy Massif; isotopic compositions of MORB and average upper crust after Zindler and Hart (1986), Late Palaeozoic alkaline rocks of the CAOB from Kovalenko et al. (2004), Permian volcanic rocks from central Inner Mongolia (Zhang et al. 2008). 

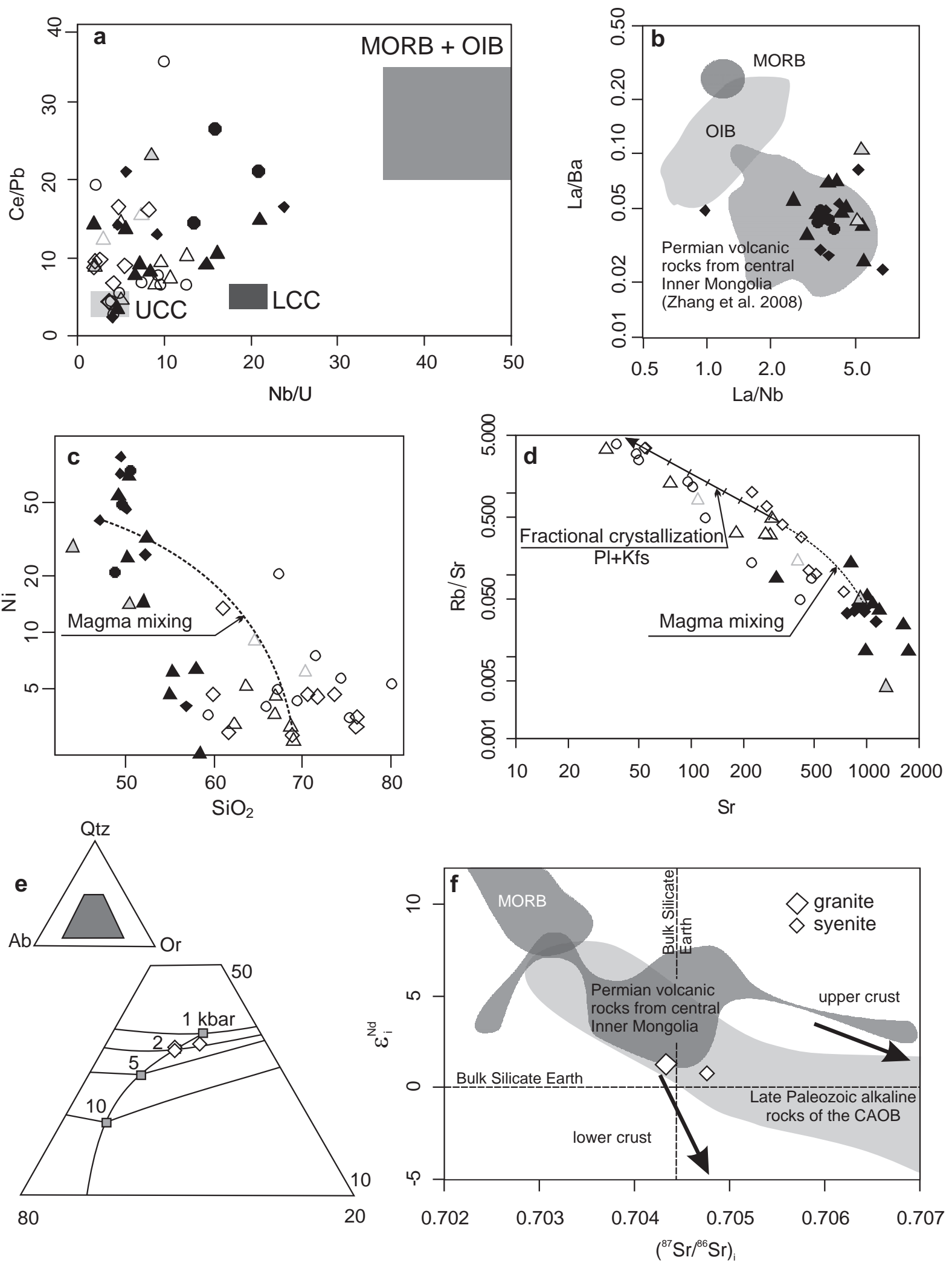

Volcanic rocks Khar Argalant Fm.

Volcanic rocks Delger Khangay Fm.

O felsic rocks

- mafic rocks
$\Delta$ felsic rocks

$\Delta$ mafic rocks
Plutonic rocks Shar Oroy Massif

$\diamond$ felsic rocks

mafic rocks $\triangle$ felsic dykes

$\triangle$ mafic dykes 
chemical characteristics are typical of granites from postcollisional suites (Pearce 1996). A post-collisional volcanic complex with comparable age, chemical and isotopic compositions was described by Zhang et al. $(2008,2011)$ from the Xilinhot area in central Inner Mongolia (North China). The Shar Oroy granites plot near the low-pressure thermal minimum on the normative $\mathrm{Qtz}-\mathrm{Ab}-\mathrm{Or}$ diagram of Johannes and Holtz (1996), which indicates a shallow level of intrusion (Fig. 11e). The CHUR-like isotopic compositions (Fig. 11f) of the felsic plutonic rocks are consistent with other Late Palaeozoic alkaline rocks of the CAOB (Kovalenko et al. 2004).

For the felsic rocks, a decrease in $\mathrm{Al}_{2} \mathrm{O}_{3}, \mathrm{FeO}_{\text {tot }}, \mathrm{MgO}$, $\mathrm{Rb}$ and $\mathrm{Ba}$ with rising $\mathrm{SiO}_{2}$ (Fig. 7) points to plagioclase, $\mathrm{K}$-feldspar and biotite fractionation. The majority of the granites with high $\mathrm{Rb} / \mathrm{Sr}$ ratios can be modelled by removing less than 50 wt. \% alkali feldspars (albite and Kfeldspar) from Sr-rich granite sample (H1182a, Fig. 11d). Feldspars are dominant minerals in the felsic rocks. Syenites have more than 70 vol. \% (K-feldspar 30 vol. \% and albite to oligoclase $\sim 40$ vol. \%) and granites $45-62$ vol. \% of alkali feldspars (K-feldspar forms 20-35 vol. $\%$ and albite to oligoclase $25-38 \mathrm{vol} . \%)$. Wide variation in modal composition and small contents of micas (15-5 vol. \%) indicate significance of alkali feldspar during fractional crystallization of the felsic rocks. The up to $45 \%$ fractional crystallization trend for felsic rocks was modelled with $\mathrm{r}=0.2$ in $5 \%$ increments (fractionating assemblage of $60 \% \mathrm{Ab}$ and $40 \% \mathrm{Kfs}$ ).

The genesis of felsic magmas can be often linked to the magmatic underplating (Huppert and Sparks 1988; Bonin 2004). The attendant magma mixing of basic and acid igneous rocks causes textural and geochemical heterogeneities (e.g. Sparks et al. 1977; Gamble 1979; Janoušek et al. 2004a; Słaby and Martin 2008), similar to those observed in some parts of the Shar Oroy Massif (e.g. mafic microgranular enclaves, presence of resorption zones in plagioclase phenocrysts, high $\mathrm{Ni}$ content in the some felsic rocks). Mafic microgranular enclaves, exposed in studied granitoids, are explained by mixing/mingling processes involving mafic and felsic magmas (e.g. Vernon 1984; Didier and Barbarin 1991; Barbarin 2005). Mantle melting would produce magmas with relatively high mg-number and high Ni contents (Fig. 7). Hyperbola-like (Fig. 11c-d) magma mixing trends are generated for $\log (\mathrm{Ni})$ versus $\mathrm{SiO}_{2}$ and $\log (\mathrm{Rb} / \mathrm{Sr})$ versus $\log (\mathrm{Sr})$ plots. However in this case is mixing trend modified by fractional crystallization (Fig. 7). Simple magma mixing trend for plutonic rocks was calculated using chemical compositions of gabbroic enclave (H1182b) and host granite (H1182a).

Permian post-collisional bimodal magmatism was commonly ascribed to continental rift settings (Mazzarini et al. 2004) and its products are frequently encountered in the Mongolian segment of the CAOB (Kovalenko et al. 2006; Yarmolyuk et al. 2008; Zhang et al. 2008; Jahn et al. 2009). The crustal extension most likely caused a thermal and mechanical instability of the thickened lithosphere (Marotta et al. 1998) during the early stages of post-collisional evolution in this part of the $\mathrm{CAOB}$, accompanied by extensive crustal anatexis.

\subsection{Age and stratigraphic relationships}

The Khar Argalant and Delger Khangay formations are of the Early to early Late Permian age as shown by fossils. All the flora remains indicate uniform, low diversity association of dry to intermediate climatic conditions, comparable with the "Cordaitean taiga" described in Siberia and amalgamated regions (Durante 1995; Chumakov and Zharkov 2002; for a rather questionable alternative viewpoint, see also Krassilov 2000) or Rufloria-Cordaites associations sensu DiMichele et al (2001) described in Siberia (Angara). All the studied vascular plant remnants belong to typically terrestrial associations. On the basis of their generic composition (dominant Rufloria with associated Cardiocarpus, Cordaites, Calamites and Annularia), these indicate a rather dry to intermediate environment (intramountain depressions?) of the temperate to cold climatic zone. The affinity of all these plant communities to the Siberian "Cordaitean taiga" may suggest a certain paleogeographical proximity (or even amalgamation) of the studied area to this continental block already in the Early Permian times (see Chumakov and Zharkov 2002 p. 593; cf. Cocks and Torsvik 2007).

The volcanic rocks are coeval with the granitoids of the Shar Oroy Massif whose emplacement was dated to $285 \pm 1 \mathrm{Ma}$. This age is slightly younger than the data of Yarmolyuk et al. (2008) from the granitic massifs related to the Main Mongolian Lineament rift zone. The Adz-Bogd Massif in western Mongolia yielded $294 \pm 5 \mathrm{Ma}$, the Mandakh Massif in eastern Mongolia $292 \pm 1$ Ma and the alkaline Khan Bogd Massif in eastern Gobi also gave a similar age of $\sim 290 \mathrm{Ma}$ (Kovalenko et al. 2010). Evidence of the Early Permian age was also described from the Variscan Gobi-Tien Shan Pluton. A granodiorite sample of its western part yielded an age of $299 \pm 8 \mathrm{Ma}$ and a leucogranite from the centre $288 \pm 15 \mathrm{Ma}$ (Hanžl et al. 2008). On the other hand, granites of the Tost and Noen ridges related to the Gobi-Tien Shan rift zone are slightly older (318 \pm 1 and $314 \pm 5 \mathrm{Ma}$; Yarmolyuk et al. 2008). This corresponds to the idea of Yarmolyuk et al. (2001 and 2005), according to which the rift-related magmatic activity in western Mongolia migrated from the south to the north.

The volcanic activity ceased during the early Late Permian age. Clastic continental sedimentary rocks (mollasse) of the Butnaa Khudag Fm. onlap onto the volcanic rocks. The composition of well-rounded pebbles in the conglomerate indicates derivation from both volcanic 
and plutonic rocks. Clasts of granites and diorites (petrographically very similar to those of the Shar Oroy Massif) in the Butnaa Khudag Fm. conglomerate confirm erosion and exhumation along normal faults (Fig. 4a) of the Shar Oroy Massif during the Late Permian.

\section{Conclusions}

The Lower Permian volcanic and plutonic system in the area of the Khar Argalant Mts. belongs to the western part of the Gobi-Altay Rift.

Two Lower Permian volcanosedimentary complexes have been distinguished. (1) The Delger Khangay Fm. includes various textural types of volcanics, such as lavas, tuffs, ignimbrites, lahars and agglomerate tuffs, i.e. products of subaerial volcanic activity. Sills and dikes of trachytes and lava domes of strongly altered rhyolites are characteristic members of the unit. Sedimentary rocks are subordinate. (2) The Khar Argalant Fm. consists of a sequence of pyroclastic rocks, tuffaceous conglomerates, breccias, sandstones, and felsic and mafic lavas.

Termination of the volcanic activity was marked by deposition of molasse sediments of the Butnaa Khudag Fm. represented by well-sorted conglomerates with layers of sandstones, marlstones and coal-bearing siltstones.

The Permian Shar Oroy Massif, which intruded the volcanic rocks of the Delger Khangay Fm., was coeval with the volcanic activity. Early Permian age of the intrusion is confirmed by the LA ICP-MS U-Pb zircon age of $285 \pm 1.3 \mathrm{Ma}$. Geochemical and structural characteristics suggest that the Shar Oroy Massif and surrounding Permian volcanic suite represent an eroded, shallow-level plutonic centre and its eruptive cover.

The style of magmatic activity and its geochemical signatures suggest that it occurred during crustal extension. As they are composed of rocks with comparable geochemical fingerprint and age, traditional subdivision of the volcanic complexes of the Khar Argalant Mts. into Delger Khangay and Khar Argalant formations is rather artificial. They seem to represent lateral variations of an extensive volcanic complex that included predominately lava flows and associated pyroclastic rocks produced in a continental environment. Paleontological findings of flora indicate uniform, low diversity association of dry to intermediate conditions, resembling the "Cordaitean taiga" described from Siberia and amalgamated regions.

Acknowledgements. The authors wish to thank J. Lexa, D. Batulzii and J. Lehmann for a critical review of the manuscript. We are also grateful to K. Hrdličková for her assistance during the manuscript preparation and V. Erban for $\mathrm{Sr}-\mathrm{Nd}$ isotopic measurements. Z. Šimůnek kindly helped with determination of the flora and with consultation of paleogeographic aspects. M. Štulíková is thanked for revising the English of this manuscript. Last but not least, the careful editorial handling by M. Štemprok and V. Janoušek helped us to improve the readability of the text. The field work was performed during the project of the geological mapping in the Mongolian Altay on a scale of 1:50 000 undertaken in the framework of the Development Assistance Project of the Czech Republic. The preparation of this manuscript was supported by the Grant Agency of Czech Republic project No. P210/12/2205.

Electronic supplementary material. The complete table of whole-rock analyses is available online at the Journal web site (http://dx.doi.org/10.3190/jgeosci.116).

\section{References}

Arndt NT, Christensen U (1992) The role of lithospheric mantle in continental flood volcanism: thermal and geochemical constraints. J Geophys Res 97(B7): 10967-10981

Badarch G, Cunnigham WD, Windley BF (2002) A new terrane subdivision for Mongolia: implications for the Phanerozoic crustal growth of central Asia. J Asian Earth Sci 21: 87-110

BARBARIN B (2005) Mafic magmatic enclaves and mafic rocks associated with some granitoids of the central Sierra Nevada Batholith, California: nature, origin, and relations with the hosts. Lithos 80: 155-177

Bonin B (2004) Do coeval mafic and felsic magmas in post-collisional to within-plate regimes necessarily imply two contrasting, mantle and crustal, sources? A review. Lithos 78: 1-24

BorZAKOVSKII YA (ed) (1985) Making of geological map and map of raw deposits of the western Mongolia (W of meridian $102^{\circ}$ ) on the scale $1: 500,000$ with explanatory text. Period I, maps M-46B, L-47A, B, V, G. Zarubezhgeologia, Moscow (in Russian)

BOYNTON WV (1984) Cosmochemistry of the rare earth elements: meteorite studies. In: HENDERSON PE (ed) Rare Earth Element Geochemistry. Elsevier, Amsterdam, pp 63-114

Buriánek D, Hanžl P, Erban V, Gilíková H, BolormaA K (2008) The Early Cretaceous volcanic activity in the western part of the Gobi-Altay Rift (Shiliin Nuruu, SW Mongolia). J Geosci 53: 167-180

Chernov E, Kovalenko D (2008) New paleomagnetic data on Carboniferous-Permian geological complexes of Mongolia. Dok Earth Sci 420: 551-553

Chumakov NM, Zharkov MA (2002) Climate during Permian-Triassic biosphere reorganizations, article 1: climate of the Early Permian. Strat Geol Correlation 10: 586-602 
Cocks LRM, ToRsviK TH (2007) Siberia, the wandering northern terrane, and its changing geography through the Palaeozoic. Earth Sci Rev 82: 29-74

Dergunov AB (2001) Tectonics, Magmatism, and Metallogeny of Mongolia. Routledge, London, pp 1-288

Didier J, Barbarin B (eds) (1991) Enclaves and Granite Petrology. Elsevier, Amsterdam, pp 1-625

Dimichele AW, Pfefferkorn HW, Gastaldo RA (2001) Response of Late Carboniferous and Early Permian plant communities to climate change. Ann Rev Earth Planet Sci 29: 461-487

DuRAnTe MV (1995) Reconstruction of Late Paleozoic climatic changes in Angaraland according to phytogeographic data. Strat Geol Correlation 3: 25-37

Ersoy Y, Helvaci C (2010) FC-AFC-FCA and mixing modeler: A Microsoft ${ }^{\circledR}$ Excel $^{\odot}$ spreadsheet program for modeling geochemical differentiation of magma by crystal fractionation, crustal assimilation and mixing. Comput Geosci 36: 383-90

Gamble JA (1979) Some relationships between coexisting granitic and basaltic magmas and the genesis of hybrid rocks in the Tertiary central complex of Slieve Gullion, northeast Ireland. J Volcanol Geotherm Res 5: 297-316

Gerdes A, Zeh A (2006) Combined U-Pb and Hf isotope LA-(MC-) ICP-MS analyses of detrital zircons: comparison with SHRIMP and new constraints for the provenance and age of an Armorican metasediment in Central Germany. Earth Planet Sci Lett 249: 47-62

Gerdes A, Zeh A (2009) Zircon formation versus zircon alteration - new insights from combined $\mathrm{U}-\mathrm{Pb}$ and $\mathrm{Lu}-\mathrm{Hf}$ in-situ La-ICP-MS analyses of Archean zircons from the Limpopo Belt. Chem Geol 261: 230-243

HANŽL P, Aichler J (eds) (2007) Geological Survey of the Mongolian Altay at a scale 1:50,000 (Zamtyn Nuruu - 50). Final report of the International Development Cooperation project of the Czech Republic. Czech Geological Survey, Brno \& MRPAM, Ulaanbaatar, pp 1-376

Hanžl P, Bat-Ulzi D, Rejchrt M, KošLer J, BolormaA K, HRDličKovÁ K (2008) Geology and geochemistry of the Palaeozoic plutonic bodies of the Trans-Altay Gobi, SW Mongolia: implications for magmatic processes in an accreted volcanic-arc system. J Geosci 53: 201-234

Hendrix MS, Graham SS, Carroll AR, Sobel ER, Mc Knight CL, Schulein BJ, Wang Z (1992) Sedimentary record and climatic implications of recurrent deformation in the Tianshan: evidence from Mesozoic strata of the north Tarim, south Junggar and Turpan basins, northwest China. Geol Soc Am Bull 104: 53-79

HrdličKová K, Bolormaa K, Buriánek D, HanžL P, Gerdes A, JANOušEK V (2008) Petrology and age of metamorphosed rocks in tectonic slices inside the Palaeozoic sediments of the eastern Mongolian Altay, SW Mongolia. J Geosci 53: 139-165
Huppert HE, Sparks RSJ (1988) Melting the roof of a chamber containing a hot, turbulently convecting fluid. J Fluid Mechanics 188: 107-131

Irvine TN, BARAGAR WRA (1971) A guide to the chemical classification of the common volcanic rocks. Can J Earth Sci 8: 523-548

JaCobsen SB, Wasserburg GJ (1980) Sm-Nd isotopic evolution of chondrites. Earth Planet Sci Lett 50: 139-155

JAHN B, Wu F, Chen B (2000) Massive granitoid generation in Central Asia: $\mathrm{Nd}$ isotope evidence and implication for continental growth in the Phanerozoic. Episodes 23: 82-92

Jahn BM, Litvinovsky BA, Zanvilevich AN, Reichow MK (2009) Peralkaline granitoid magmatism in the Mongolian-Transbaikalian Belt: evolution, petrogenesis and tectonic significance. Lithos 113: 521-539

Janoušek V, Braithwaite CJR, Bowes DR, Gerdes A (2004a) Magma-mixing in the genesis of Hercynian calc-alkaline granitoids: an integrated petrographic and geochemical study of the Sázava intrusion, Central Bohemian Pluton, Czech Republic. Lithos 78: 67-99

Janoušek V, Finger F, Roberts M P, Frýda J, Pin C, Dolejš $\mathrm{D}$ (2004b) Deciphering the petrogenesis of deeply buried granites: whole-rock geochemical constraints on the origin of largely undepleted felsic granulites from the Moldanubian Zone of the Bohemian Massif. Trans Roy Soc Edinb, Earth Sci 95: 141-159

JANOUŠEK V, FARROW CM, ERBAN V (2006) Interpretation of whole-rock geochemical data in igneous geochemistry: introducing Geochemical Data Toolkit (GCDkit). J Petrol 47: $1255-1259$

Johannes W, Holtz F (1996) Petrogenesis and Experimental Petrology of Granitic Rocks. Springer-Verlag, Berlin, pp 1-335

Kovalenko D, Chernov E (2008) Paleomagnetism of Carboniferous-Permian and early Jurassic geological complexes in Mongolia. Izvestiya Phys Solid Earth 44: 427-441

Kovalenko, VI, Yarmolyuk VV, Kovach VP, Kotov AB, Kozlovsky AM, SAL'NiKova EB, Larin AM (2004) Isotope provinces, mechanisms of generation and sources of the continental crust in the Central Asian Mobile Belt: geological and isotopic evidence. J Asian Earth Sci 23: 605-627

Kovalenko V, Yarmoluyk V, Sal'nikova E, Kozloviky A, Kotov A, Kovach V, Savatenkov V, Vladykin N, PonomarchuK V (2006) Geology, geochronology, and geodynamics of the Khan Bogd alkali granite pluton in southern Mongolia. Geotectonics 40: 450-466

Kovalenko V, Kozlovsky A, Yarmolyuk V (2010) Comendite-bearing subduction-related volcanic associations in the Khan-Bogd area, southern Mongolia: geochemical data. Petrology 18: 571-595

KrassiLOV VA (2000) Permian phytogeographic zonality and its implications for continental positions and climates. Palentol J 34 (Suppl. I): 587-598 
Kröner A, Lehmann J, Schulmann K, Demoux A, Lexa O, TomurhuU D, ŠTí́sské P, Liu D, Wingate WTD (2010) Lithostratigraphic and geochronological constraints on the evolution of the Central Asian Orogenic Belt in SW Mongolia: early Paleozoic rifting followed by late Paleozoic accretion. Amer J Sci 310: 523-574

Lamb M, Badarch G (2001) Paleozoic sedimentary basins and volcanic-arc systems of southern Mongolia: new stratigraphic and petrographic constraints. In: HENDRIX MS, Davis GA (eds) Paleozoic and Mesozoic Tectonic Evolution of Central Asia - From Continental Assembly to Intracontinental Deformation. Geological Society of America Memoirs 194: 117-150

Le Bas MJ, Le Maitre RW, Streckeisen A, Zanettin B (1986) A chemical classification of volcanic rocks based on the total alkali-silica diagram. J Petrol 27: 745-750

Lehmann J, Schulmann K, Lexa O, Corsini M, Kröner A, ŠTíPSKÁ P, TOMURHUU D, OtgONBATOR D (2010) Structural constraints on the evolution of the Central Asian Orogenic Belt in southern Mongolia. Amer J Sci 310: 575-628

Lugmair GW, Marti K (1978) Lunar initial ${ }^{143} \mathrm{Nd} /{ }^{144} \mathrm{Nd}$ : differential evolution line of the lunar crust and mantle. Earth Planet Sci Lett 39: 349-357

MaRKova NG (1975) Stratigraphy of the Lower and Middle Paleozoic of Western Mongolia.Transactions of Joint Soviet-Mongolian Scientific Research Geological Expedition, 12. Nauka, Moscow, pp 1-119 (in Russian)

Marotta AM, Fernandez M, Sabadini R (1998) Mantle unrooting in collisional settings. Tectonophysics $296: 31-46$

MazZarini F, Corti G, Manetti P, InNocenti F (2004) Strain rate and bimodal volcanism in the continental rift: Debre Zeyt volcanic field, northern MER, Ethiopia. J Afr Earth Sci 39: 415-420

MiddLemost EAK (1994) Naming materials in the magma/ igneous rock system. Earth Sci Rev 37: 215-224

Pearce JA (1996) Sources and settings of granitic rocks. Episodes 19: 120-125

Pearce JA, Norry MJ (1979) Petrogenetic implications of $\mathrm{Ti}, \mathrm{Zr}, \mathrm{Y}$, and $\mathrm{Nb}$ variations in volcanic rocks. Contrib Mineral Petrol 69: 33-47

Pearce Ja, Harris NBW, Tindle AG (1984) Trace element discrimination diagrams for the tectonic interpretation of granitic rocks. J Petrol 25: 956-983

Rauzer AA, Zhanchiv DI, Golyakov VI, Ykhina IF, Ivanov IG, Tsukernik AB, Afonin VV, Smirnov IG, Bykhover VI, Kravtsev AV, Batarkhuyag A, Skoryukin MI, Khodikov IV, Mantsev NV, Okaemov SV, Mischin VA , ENKHSAJKHAN T (1987) Report on results of geological mapping on scale 1:200,000 in the south-western part of Mongolian Altay in 1983-1986, Mongolian National Republic. Tekhnoexport, Moscow, pp 1-352 (in Russian)

Richard P, Shimizu N, Allégre CJ $(1976){ }^{143} \mathrm{Nd} /{ }^{146} \mathrm{Nd}$, a natural tracer: an application to oceanic basalts. Earth Planet Sci Lett 31: 269-278
Rudnick RL, GaO S (2003) Composition of the Continental Crust. In: Rudnick RL (ed) The Crust. In: Holland HD, Turekian KK (eds) Treatise on Geochemistry 3. Pergamon, Oxford, pp 1-64

Ruzhentsev S (2001) The Variscan belt of south Mongolia and Dzungaria. In: Dergunov AB (ed) Tectonics, Magmatism, and Metallogeny of Mongolia. Routledge, London, pp 61-94

Sengör AMC, Natal' in BA, Burtman VS (1993) Evolution of the Altaid tectonic collage and Paleozoic crustal growth in Eurasia. Nature 364: 299-307

SŁaby E, Martin H (2008) Mafic and felsic magma interaction in granites: the Hercynian Karkonosze Pluton (Sudetes, Bohemian Massif). J Petrol 49: 353-391

Sparks R S J, Sigurdsson H, Wilson L (1977) Magma mixing: a mechanism for triggering acid explosive eruptions. Nature 267: 315-318

Steiger RH, JäGer E (1977) Subcommission on Geochronology; convention on the use of decay constants in geo- and cosmochronology. Earth Planet Sci Lett 36: 359-362

Sun SS, McDonough WF (1989) Chemical and isotopic systematics of oceanic basalts: implications for mantle composition and processes. In: SAUNDERs AD, NORRY MJ (eds) Magmatism in Ocean Basins. Geological Society of London Special Publications 42: 313-345

Štípská P, Schulmann K, Lehmann J, Corsini M, Lexa O, Tomurhuu D (2010) Early Cambrian eclogites in SW Mongolia: evidence that the Palaeo-Asian Ocean suture extends further east than expected. J Metamorph Geol 28: 915-933

TAYLOR SR, McLennan SM (1995) The geochemical evolution of the continental crust. Rev Geophys 33: 241-265

Tomurtogoo O (1997) A new tectonic scheme of the Paleozoides in Mongolia. Mong Geosci 3: 12-19

VERNON RH (1984) Microgranitoid enclaves in granites - globules of hybrid magma quenched in a plutonic environment. Nature 309: 438-439

Whalen JB, Currie KL, Chappell BW (1987) A-type granites - geochemical characteristics, discrimination and petrogenesis. Contrib Mineral Petrol 95: 407-419

Wood DA (1980) The application of a Th-Hf-Ta diagram to problems of tectonomagmatic classification and to establishing the nature of crustal contamination of basaltic lavas of the British Tertiary Volcanic Province. Earth Planet Sci Lett 50: 11-30

Xiao W, Windley BF, Hao J, Zhai M (2003) Accretion leading to collision and the Permian Solonker Suture, Inner Mongolia, China: termination of the central Asian orogenic belt. Tectonics 22: 1069, doi: 10.1029/2002TC001484

Xiao WJ, Windley BF, Badarch G, Sun S, Li J, Qin K, WANG Z (2004) Palaeozoic accretionary and convergent tectonics of the southern Altaids: implications 
for the growth of central Asia. J Geol Soc, London 161: $1-4$

Xiao WJ, Han CM, Yuan C, Sun M, Lin SF, Chen HL, Li ZL, Li JL, Sun S (2008) Middle Cambrian to Permian subduction-related accretionary orogenesis of North Xinjiang, NW China: implications for the tectonic evolution of Central Asia. J Asian Earth Sci 32: 102-117

Xixi Z, Coe R S, Yaoxiu Z, Haoruo W, Jie W (1990) New paleomagnetic results from northern China: collision and suturing with Siberia and Kazakhstan. Tectonophysics 181: 43-81

YARMOLYUK VV (1983) Late Palaeozoic Volcanism in the Continental Rift Structures of Central Asia. Nauka, Moscow, pp 1-198 (in Russian)

YARMOLYUK VV, KoVALENKo VI (1991) Rift magmatism of active continental margins and its ore potential. Nauka, Moscow, pp 1-263 (in Russian)

Yarmolyuk VV, Kovalenko VI (2001) Late Riphean breakup between Siberia and Laurentia: evidence from intraplate magmatism. Dokl Earth Sci 379: 525-528

Yarmolyuk VV, Litvinovsky BA, Kovalenko VI, Jahn BM, Zanvilevich AN, Vozontsov AA, Zhuravlev DZ, PosoKHov VF, KuzMin DV, SANDimirova GP (2001) Formation stages and sources of the peralkaline granitoid magmatism of the northern Mongolian-Transbaikakia Rift Belt during Permian and Triassic. Petrology 9: 302-328

Yarmolyuk VV, Kovalenko VI, Kozlovsky AM, VoRontsov AA, Savatenkov VM (2005) Late Paleozoic-Early Mesozoic rift system of Central Asia: composition of magmatic rocks, sources, order of formation and geodynamics. In: KovalENKo VI (ed) Tectonic Problems of Central Asia. World of Science, Moscow, pp 197-226

Yarmolyuk VV, Kovalenko V, Sal'nikova E, Kovach V, Kozlovsky A, Kotov A, Lebedev V (2008) Geochronol- ogy of igneous rocks and formation of the Late Paleozoic south Mongolian active margin of the Siberian continent. Strat Geol Correlation 16: 162-181

ZАвоткIN LB (ed) (1983) Report on results of geological mapping on scale 1:200,000 in the Central-Gobi region of Mongolian National Republic in 1979-1982. Moscow (in Russian)

Zaitsev NS, Luwsandansan B, Marinov NA, Menner VV, Pavlova tG, Peive AV, Timofeev PP, Tomurtogoo O, YANShin AL (1970) Stratigraphy and tectonics of the Mongolian Peoples' Republic, v. 1. Transactions of Joint Soviet-Mongolian Scientific Research Geological Expedition. Nauka, Moscow, pp 1-148 (in Russian)

Zhang X, Zhang H, Tang Y, Wilde SA, Hu Z (2008) Geochemistry of Permian bimodal volcanic rocks from central Inner Mongolia, North China: implication for tectonic setting and Phanerozoic continental growth in Central Asian Orogenic Belt. Chem Geol 249: 262-281

Zhang X, Wilde SA, Zhang H, Zhai M (2011) Early Permian high-K calc-alkaline volcanic rocks from NW Inner Mongolia, North China: geochemistry, origin and tectonic implications. J Geol Soc, London 168: 525-543

Zhou JC, WAng XL, Qiu JS, Gao JF (2004) Geochemistry of Meso- and Neoproterozoic mafic-ultramafic rocks from northern Guangxi, China: arc or plume magmatism? Geochem J 38: 139-152

Zhu YF, Sun SH, Gu LB, Ogasawara Y, Jiang N, Honwa $\mathrm{H}$ (2001) Permian volcanism in the Mongolian orogenic zone, northeast China: geochemistry, magma sources and petrogenesis. Geol Mag 138: 101-115

Zindler A, Hart S (1986) Chemical Geodynamics. Ann Rev Earth Planet Sci 14: 493-571

Zonenshain LP (1973) The evolution of Central Asiatic geosynclines through sea-floor spreading. Tectonophysics 19: 213-232 